\title{
MATIČNA KNJIGA KRŠTENIH ŽUPE CRES (1571. - 1596.)
}

Maria Paola POROPAT

Sisplac 17, Pula

mp.poropat@gmail.com
UDK 711.436:929.53]

(497.571Cres)“"1571/1576“

Izvorni znanstveni rad

https://doi.org/10.31726/via.27.6

Rad predstavlja istraživanje Matične knjige krštenih župe Cres u razdoblju od 1571. do 1596., s osvrtom na analizu rukopisa, godišnji i mjesečni raspored rođenja, potom mjesečni raspored začeća te vezu začeća sa sezonskim poslovima. Nadalje, osvrće se na nadijevanje imena krštenicima te donosi muška i ženska imena, ali i pridjevke (prezimena) očeva krštenika. Uz spomenuto, analiziran je i broj upisa koji se odnosi na blizanačke parove, a koji su bili vrlo rijetki u župi Cres u promatranom razdoblju. Zatim se analizira struktura kumstva te njihov broj u pojedinim upisima. Rad je uspoređivan s istraživanjima koja su provedena za obližnja, ponajprije istarska mjesta.

Ključne riječi: Matična knjiga krštenih župe Cres, rani novi vijek, rukopis, raspored rođenja i začeća, muška i ženska imena, pridjevci/prezimena

Keywords: register of Baptisms of the Parish of Cres, early modern period, manuscript, distribution pattern of births and conceptions, male and female names, epithets / surnames

Parole chiave: il registro dei battezzati della parrocchia di Cherso, prima età moderna, scrittura, distribuzione di nascite e concepimenti, nomi maschili e femminili, appellativi/cognomi

\section{Uvod}

O povijesti grada Cresa i njegova stanovništva pisali su mnogi autori - Fučić, Imamović, Solis, Dlačić, Lemessi, Bertoša, Vlahović... Svaki je od njih proučavao određen segment - bratovštine, crkve, statut, zavičajnu povijest, dok su neki, kao Imamović, pisali o mletačkoj vlasti na otoku tijekom razdoblja srednjega i novog vijeka. Fučić se, primjerice, bavio poviješću otoka od antike pa do suvremenosti te je u svojim djelima nastojao zabilježiti legende, predaje, a navodi i lokalitete koje bi bilo vrijedno obići prilikom boravka na otoku. Navedeni su autori istraživali i pisali o gotovo svim segmentima povijesti otoka, osim o matičnim knjigama, koje su u žarištu ovoga istraživanja.

U radu ćemo analizirati Matičnu knjigu krštenih župe Cres za razdoblje od 1571. do 1596. godine. Originalan se rukopis čuva u Hrvatskom državnom arhivu u Zagrebu. ${ }^{1} \mathrm{Pi}$ -

1 Dostupno: https://www.familysearch.org/search/catalog/681513?availability=Family\%20History\%20Library (pristup 3. 3. 2020.). Navedeno kao mikrofilmska građa: Matične knjige rimokatolika, Župa Cres, 
sali su ga rimokatolički svećenici za potrebe bilježenja krštene djece. Iako je dvadeset pet godina relativno kratko razdoblje za donošenje dalekosežnijih zaključaka o kretanju broja rođenih, izboru imena, čestim prezimenima/pridjevcima te kretanju začeća, nastojat ćemo prikazati rezultate do kojih smo došli analizom prikupljenih podataka. Podatci će biti uspoređeni s podatcima drugih mjesta, ponajprije susjednih istarskih, za koje su već izrađene analize. Naime, demografsku analizu creske župe bilo bi dobro usporediti i sa susjednim župama i otocima, poput Krka i Raba, međutim, za njih još nisu napravljene takve analize. Stoga ćemo usporedbu raditi s onim mjestima, prvenstveno istarskim, koja također pripadaju mediteranskom, i to sjevernojadranskom kulturnom krugu, a za koja su analize već napravljene.

\section{Cres u novom vijeku}

Kontinuitet življenja na otoku Cresu moguće je pratiti još od rimskoga vremena pr. Kr., zatim slijedi bizantski period vladanja otokom, da bi otokom u ranom srednjem vijeku vladali hrvatski narodni vladari. Povijest otoka moguće je pratiti u više aspekata, kao što su kultura, jezik, arheološka i ostala materijalna baština. Mnoge od crkava na otoku danas su u ruševnu stanju, međutim, brojnost tih ostataka i njihovi temelji svjedoče o tome koliko je veliku ulogu igrala Crkva i religioznost u životima ondašnjih ljudi. Cres je, kao i drugi otoci, izoliran od kopnenoga dijela, što donekle usporava kretanja ideja, misli i ljudi. Ipak, ta je tvrdnja uvelike paušalna jer se u razdoblju koje proučavamo puno više kretalo morem, pa u tom smislu ni Cres nije bio izoliran od putnika, došljaka i utjecaja s kopna i iz drugih dijelova Mediterana. Određena ograničenost samoga otoka ogleda se u skučenim prirodnim i prostornim resursima što, naravno, utječe i na prirodni prirast. ${ }^{2}$ Ratovi i ostale nepovoljne prilike na kontinentu inicirali su migracije ljudi koji su svoje utočište najčešće pronalazili u udaljenijim krajevima ili na otocima, čija je izoliranost u takvim prilikama bila pozitivnom karakteristikom. Primjerice, nakon pada Bosne pod osmansku vlast 1463. godine mnogi su svoje utočište tražili upravo na otocima. U 13. je pak stoljeću plemićka obitelj Petris, bježeći pred Mongolima s kraljem Belom IV., doselila na otok Cres 1242. godine. $^{3}$

Tijekom ranoga i dijelom razvijenoga srednjeg vijeka Cres je bio pod vlašću hrvatskih i potom hrvatsko-ugarskih vladara, ali je zbog svojega geografskog položaja predstavljao i važnu pomorsku postaju prema Veneciji koja se počela zanimati za njega i za druge gradove na dalmatinskoj obali. Uslijedilo je razdoblje mletačkih ratova u kojem je Republika

Matična knjiga rođenih (1571. - 1596.), Tom. I. (68), Hrvatski državni arhiv u Zagrebu.

2 Marijana DLAČIĆ, $\gg$ Razvoj naselja na otoku Cresu u razvijenom i kasnom srednjem vijeku s obzirom na značajke stanovništva - primjer crkava posvećenih sv. Antunu opatu, zaštitniku stoke i stočara«, u: Creski anali: od starine do našega doba, sv. I, ur. Slaven BERTOŠA, Sveučilište Jurja Dobrile u Puli, Pula, 2018., str. 19.

3 Nicolò LEMESSI, Note storiche - geografiche - artistiche sull' isola di Cherso, vlastita naklada, Rim 1979., str. 93; Enver IMAMOVIĆ, Otoci Cres i Lošinj od ranog srednjeg vijeka do konca XVIII stoljeća, Zavičajna biblioteka 1, Mali Lošinj, 1987., str. 29; Jasminka CUS-RUKONIĆ, »Osorska heraldička baština (I. dio)«, u: Creski anali..., str. 82 i 83. 
Svetoga Marka nastojala preuzeti vlast na spomenutom prostoru te dolazi do takozvane prve mletačke uprave koja je trajala od 1145. do 1358. godine. Drugo je razdoblje mletačke vlasti uslijedilo nakon prodaje Dalmacije 1409. godine, kada započinje dugotrajna vlast Republike nad Dalmacijom i otocima sve do njezina ukinuća 12. svibnja 1797. ${ }^{4}$

Na otok su dolazili i mnogi trgovci, obrtnici i činovnici iz mletačkoga zaleđa te se tako razvijao dotok ideja, roba i ljudi na otoku. Prepoznajemo ih po prezimenima/pridjevcima tipičnim za područje odakle su doseljavali - Balbi, Bembo, Giusti, Gradenigo, Grimani, Lion, Malipiero, Mitis, Morosini, Nigris, Querini, Zorzi. ${ }^{5}$

Prije dolaska mletačke vladavine Cres je bio podijeljen na četiri općine - Beli, Lubenice, Cres i Osor. ${ }^{6}$ Hrvatsko-ugarski kraljevi dodijelili su otoku statut 1332. godine. Prema statutu Cres je imao status kaštela u kojemu su nositelji vlasti bili podžupan i sudci. Za vrijeme mletačke vlasti središte otoka postaje Osor te je tom prilikom došlo do usvajanja novoga statuta koji je objedinio statute prijašnjih četiriju općina (Beli, Lubenice, Cres, Osor). Poznat je pod nazivom Statut Cresa i Osora, izdan 1437. godine. Statut je potvrdio mletački dužd Francesco Foscari 1440., a cresko ga je vijeće također potvrdilo već sljedeće godine.

Nakon 1450. dolazi do odumiranja Osora kao središta otoka jer su se svjetovni i crkveni predstavnici vlasti selili u Cres. Stoga dolazi do nagla razvoja grada Cresa, grade se potrebne zgrade kako bi predstavnici obiju vlasti bili primjereno smješteni - 1478. gradi se župna crkva Gospe Snježne kao trobrodna crkva s dvjema renesansnim arkadama pod vodstvom biskupa Marca Nigrisa, čiji se potpis može naći iznad portala. ${ }^{8}$

Knez je, kao predstavnik vlasti na otoku, biran u Veneciji te je njegova služba bila vremenski ograničena. Za svoj boravak primao je plaću, u izvorima ga se navodi kao comitus, comitis, comes, conte ili, pak, kao conte et capitano. Predstavljao je administrativnu i vojnu vlast te mu je glavna zadaća bila ostvarivati ciljeve koji mu je Republika zadala. Pratnju kneza činili su kancelar (bilježnički poslovi), kavaljer (knežev pratitelj koji je morao biti stranac čija je služba bila ograničena na dvije godine te nakon isteka službe više nije mogao obnašati nikakve službe na otoku), notar, kamerlengo, koji je bio zadužen za financije, i razni pomoćnici, tj. coadiutori. Svi su spomenuti predstavnici vlasti potvrđivani u Veneciji

\footnotetext{
IMAMOVIĆ, Otoci Cres i Lošinj..., str. 29; DLAČIĆ, »Razvoj naselja na otoku Cresu...«, str. 21.
}

IMAMOVIĆ, Otoci Cres i Lošinj..., str. 47; DLAČIĆ, »Razvoj naselja na otoku Cresu...«, str. 78.

6 Marijana DLAČIĆ, Bratovštine na području bivše osorske komune, Lošinjski muzej, Mali Lošinj, 2014. str. 5.

7 Tomislav GALOVIĆ, »Statut Cresa i Osora«, u: Suzbijanje korupcije u Hrvatskoj u srednjem vijeku, ur. Zorislav Antun PETROVIĆ, Kultura i Etika, Zagreb, 2016., str. 54; DLAČIĆ, Bratovštine..., str. 5-6.

8 Inge SOLIS, Crkve i kapele cresko-lošinjskog arhipelaga I dio, Creski muzej pri Pučkom otvorenom učilištu, Mali Lošinj, 2014., str. 87; ĆUS-RUKONIĆ, »Osorska heraldička baština...«, str. 75. Vidi i: Jasenka GUDELJ, »Zborna crkva sv. Marije Snježne u Cresu«, u: Renesansa i renesanse u umjetnosti Hrvatske, ur. Predrag MARKOVIĆ - Jasenka GUDELJ, Institut za povijest umjetnosti, Zagreb, 2008. str. 149-166. 
pa je tako i jezik administracije bio talijanski s izraženim mletačkim dijalektom, koji je počeo istiskivati hrvatski jezik. ${ }^{9}$

Svetac zaštitnik grada Cresa jest sveti Sidar, tj. sveti Izidor, koji je bio rodom iz Aleksandrije. Služio je u mornarici rimske vojske za vrijeme cara Decija I. Zbog svoje karijere našao se na meti ljubomornoga mornara koji ga je tužio zapovjedniku da je kršćanin. Pri ispitivanju Izidor nije zanijekao svoju vjeru, nego ju je odlučno branio, na što je zapovjednik odredio da mu se odreže jezik i odsiječe glava. Tijelo mu je bilo vezano za konja koji je nagnan u trk gradom, a naknadno je tijelo i zapaljeno. Amonio, Izidorov prijatelj, sakupio je ono što je od njega ostalo i sakrio kako neprijatelji ne bi sve uništili. Jedan je dio relikvija mučenika prebačen u Carigrad, gdje mu je sagrađena crkva, dok je drugi dio ostao na grčkom otoku Hiju, gdje mu je također podignuta crkva. U 12. stoljeću mletački je dužd organizirao neovlašten prijenos relikvija u Veneciju - ondje su 1355. postavljene u crkvi sv. Marka. Štovanje svetaca imalo je posebno značenje i njihov se dan posebno obilježavao. ${ }^{10}$

U gradu Cresu postojala je crkva sv. Izidora, koji je bio zaštitnik grada. Njegova se važnost ogledala u tome što su članovi vijeća nakon sjednica obvezno išli u crkvu sv. Izidora. Odlučeno je 1543. da se nabavi plašt sv. Sidra koji bi nosili samo plemići, tj. oni koji smiju nositi oružje, a plašt se nosio i u povorci na blagdan sv. Sidra, 2. siječnja. ${ }^{11}$

\section{Analiza rukopisa}

Najstarija sačuvana Matična knjiga krštenih župe Cres, koja je i predmetom ove analize, pisana je u razdoblju od 1571. do 1596., a pisalo ju je čak trideset svećenika. Svaki je svećenik, što je i sasvim razumljivo, imao poseban stil pisanja i različit način oblikovanja slova. Matica je pisana talijanskim jezikom, odnosno mletačkim dijalektom, koji je bio svojstven ovom geografskom području zbog gotovo kontinuirane nazočnosti mletačke vlasti. Matične knjige vođene na istarskom području također su vođene na talijanskom i latinskom jeziku, a neke od njih imale su stranice ispisane na glagoljici, ${ }^{12}$ međutim, $u$ analiziranoj creskoj matičnoj knjizi nije zabilježen ni jedan takav slučaj. U rukopisu smo naišli na pojedine latinske fraze, ali nismo zabilježili nijedan hrvatski izraz. U nastavku ćemo nastojati iznijeti neke specifičnosti na koje smo naišli pri analiziranju samoga rukopisa.

Mnogi su svećenici-upisivači koristili brojne kratice koje su omogućavale brže pisanje i štednju papira. Kraćenje riječi ovisilo je o pojedinom svećeniku, a kratilo se sve, od osobnih imena, titula, datuma, prijedloga i slično. Primjerice: $q$-quondam; mad.a-madonna; m.ro-mistro; ms - miser; pre - presbiter; s.r-signor; cap.o-capitano; Nic.o - Nicolò; And.a-Andrea; Jac.o - Jacomo, Jacopo; Gasp.o - Gasparo; Cat.a-Cattarina; p.o - pri-

9 IMAMOVIĆ, Otoci Cres i Lošinj..., str. 49 i 60; Josip VLAHOVIĆ, Odlomci iz povijesti grada Cresa, vlastita naklada, Zagreb, 1995., str. 62; ĆUS-RUKONIĆ, »Osorska heraldička baština...«, str. 75.

10 VLAhOVIĆ, Odlomci iz povijesti grada Cresa.., str. 81.

11 Isto, str. 80

12 Danijela DOBLANOVIĆ ŠURAN - Marija MOGOROVIĆ CRLJENKO, Matična knjiga krštenih župe Umag (1483. - 1643.), Državni arhiv u Pazinu (dalje: DAPA), Pazin, 2019., str. 17. 
mo; x.bre - decembre; 8.brio - ottobrio..., a nerijetko su kratili i vlastito ime stvarajući specifičan znak za njega.

Evo nekih osobitosti rukopisa, koje su, zapravo, karakteristične za mnoge rukopise pisane humanistikom.

Kao znak za rastavljanje riječi korišten je znak jednako $(=)$ ili dvotočka (:), koji se upotrebljavao na kraju stranice, a označavao je nastavak riječi u novom redu. Crta iznad riječi označava kraćenje slova $m$ ili $n$ (npr. copare - compare). Premda se uobičajeno koristi grafem $c$ za riječi koje u današnjem rječniku započinju slovom $k$., u rukopisu postoji i korištenje grafema $K$. To pokazuje upis od 26. prosinca 1583., kad je krštena Lucia Katalina, a čija je majka navedena imenom Catarina. Slova $z z$ ponekad zamjenjuju slova $g g$ što je vidljivo u prezimenu Rizzo koje je ponekad zapisano i kao Riggo. Teško je utvrditi koji je oblik prezimena točan jer su oba oblika u uporabi. Naime, pojedini članovi ove obitelji u različitim su se prilikama potpisivali na oba navedena načina.

Nismo uočili uporabu crteža, međutim, primjer upisa iz 4. travnja 1580. predstavlja izuzetak. Naime, ispred upisa nacrtana je ruka na kojoj je skakavac. Kršćanska simbolika skakavca $^{13}$ predstavlja kao negativnu pojavu, pa je moguća pretpostavka da je u spomenutoj godini bila oskudica hrane, nerodna godina ili, pak, prikazuje trenutnu inspiraciju pisara u danom trenutku. Teško je sa sigurnošću utvrditi o čemu se točno radi. ${ }^{14}$

Brojevi su pisani arapskim brojkama, ali ako se radilo o prvom i zadnjem danu u mjesecu, oni su vrlo često zapisivani riječima primo i ultimo.

Sva imena na koja smo naišli, napisana su u talijanskoj formi. Čak su i svećenici svoja imena prevodili, no na fol. 97 svećenik koji se inače potpisuje kao Zuane Iuriacho upisan je kao Ivan Iuriacho, što daje naslutiti kako vjerojatno postoji još ovakvih slučajeva. Možda dotični nije sam upisivao nego ga je za njega obavio neki drugi svećenik. Teško je sa sigurnošću utvrditi istinitost ovih pretpostavki, kao i činjenicu u kojem su broju i omjeru osobna imena i prezimena upisivana u talijanskim oblicima, a u praksi se koristila u hrvatskim oblicima.

13 Usp. Marijan STEINER, Govor kršćanskih simbola, Filozofsko-teološki institut Družbe Isusove, Zagreb, 2009., str. 56.

Ipak, niže je u Tablici 1. vidljivo da je 1581. rođeno svega tridesetšestero djece (gotovo dvostruko manje od uobičajena prosjeka!). Poznato je da se nerodne godine, godine gladi, kužne epidemije manifestiraju i u broju rođene djece, uglavnom u godini koja slijedi jer se začeća djece tijekom tih kriznih godina događaju u puno manjoj mjeri pa je i djece u sljedećoj godini znatno manje. Broj rođene djece u 1581 . godini, dakle, potvrđuje da se prethodne godine dogodio »skakavac« - po svemu sudeći epidemija gripe, koja je dugo u historiografiji tretirana kao kužna epidemija. Ona je zaista i harala Europom te godine Te je godine, primjerice, talijanskom skladatelju Giovanniju Pierluigiju da Palestrini u epidemiji u Rimu umrla supruga (u kužnim epidemijama ranijih godina i dvojica sinova), a on ju je jedva preživio; usp. »Palestrina, Giovanni Pierluigi da«, Hrvatska enciklopedija, mrežno izdanje, Leksikografski zavod Miroslav Krleža, 2020., http://www.enciklopedija.hr/Natuknica.aspx?ID=46254 (pristupljeno 2. 9. 2020.). 


\section{Rođenja, krštenja i začeća}

\section{Godišnji raspored rođenja}

U Matičnoj knjizi krštenih župe Cres u razdoblju od 1571. do 1596. zabilježeno je 1688 krštenja djece, od kojih 883 (52,3\%) dječaka i 805 (47,7 \%) djevojčica. Godišnje se prosječno rađalo 67,5 djece. Prema spolu u zadanom je razdoblju prosječno po godini rođeno 31,9 ženske djece dok je muške prosječno po godini rođeno 35,6 - što govori kako se prosječno rađalo više muške nego ženske djece. Navedene podatke treba uzeti s rezervom jer ne možemo biti sigurni jesu li upisana baš sva rođena djeca.

Iz tablice možemo vidjeti kako je u nekim godinama zabilježen vrlo mali broj krštenja, odnosno rođenja djece, dok neke godine bilježe više rođene djece nego što je bio godišnji prosjek. Periodi manjega rađanja djece obuhvaćaju razdoblje od 1571. do 1575., kada je kršteno ukupno 184, i razdoblje od 1579. do 1581., kada je bilo rođeno 144 djece. Prosjek je rođenih u periodu od 1571. do 1575 . godine 36,8 djece, dok je u periodu od 1579. do 1581 . bio 48 djece. U analiziranom razdoblju najviše je rođenih bilo između 1585. i 1592. godine, kad je ukupno rođeno 667 djece. U ovom je razdoblju prosječno bilo rođeno 83,3 djece.

\begin{tabular}{|c|c|c|c|}
\hline Godina & Ženska djeca & Muška djeca & Ukupno djece \\
\hline 1571. & 6 & 3 & 9 \\
\hline 1572. & 14 & 17 & 31 \\
\hline 1573. & 20 & 17 & 37 \\
\hline 1574. & 31 & 32 & 63 \\
\hline 1575. & 17 & 27 & 44 \\
\hline 1576. & 27 & 38 & 65 \\
\hline 1577. & 33 & 35 & 68 \\
\hline 1578. & 32 & 33 & 65 \\
\hline 1579. & 29 & 27 & 56 \\
\hline 1580. & 26 & 26 & 52 \\
\hline 1581. & 11 & 25 & 36 \\
\hline 1582. & 25 & 35 & 60 \\
\hline 1583. & 40 & 45 & 85 \\
\hline 1584. & 23 & 33 & 56 \\
\hline 1585. & 44 & 47 & 91 \\
\hline 1586. & 47 & 37 & 84 \\
\hline 1587. & 46 & 49 & 95 \\
\hline 1588. & 37 & 42 & 79 \\
\hline 1589. & 33 & 39 & 72 \\
\hline 1590. & 44 & 47 & 91 \\
\hline 1591. & 31 & 42 & 73 \\
\hline 1592. & 28 & 54 & 82 \\
\hline 1593. & 41 & 28 & 69 \\
\hline 1594. & 43 & 41 & 84 \\
\hline 1595. & 37 & 35 & 72 \\
\hline \multirow[t]{2}{*}{1596.} & 33 & 36 & 69 \\
\hline & 798 & 890 & 1688 \\
\hline
\end{tabular}

Tablica 1. Odnos rođene djece po godinama u župi Cres 


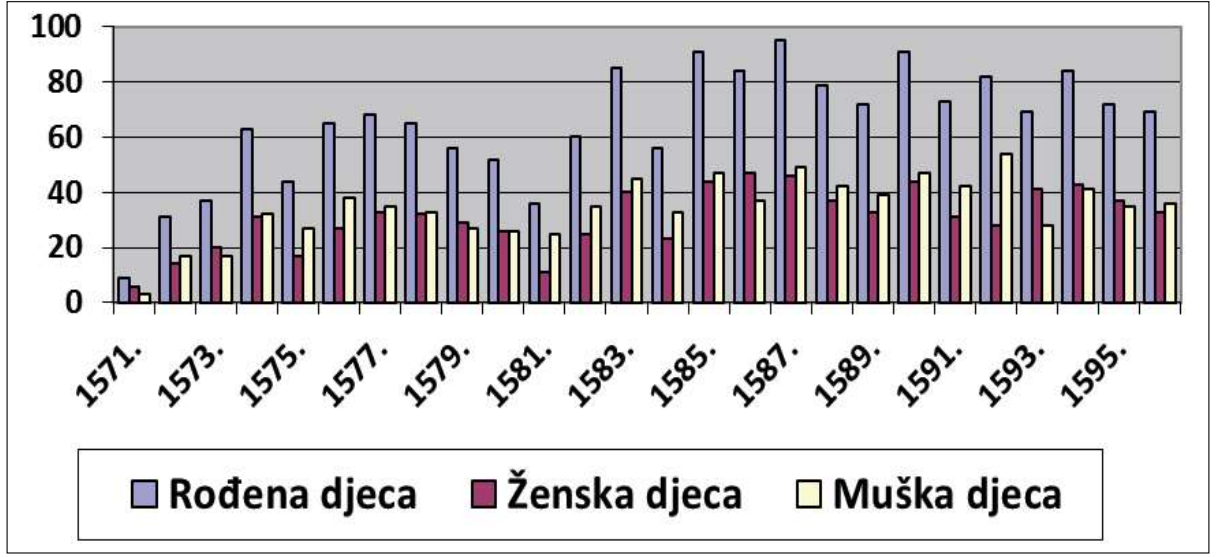

Grafikon 1. Prikaz rođenih po godinama u župi Cres

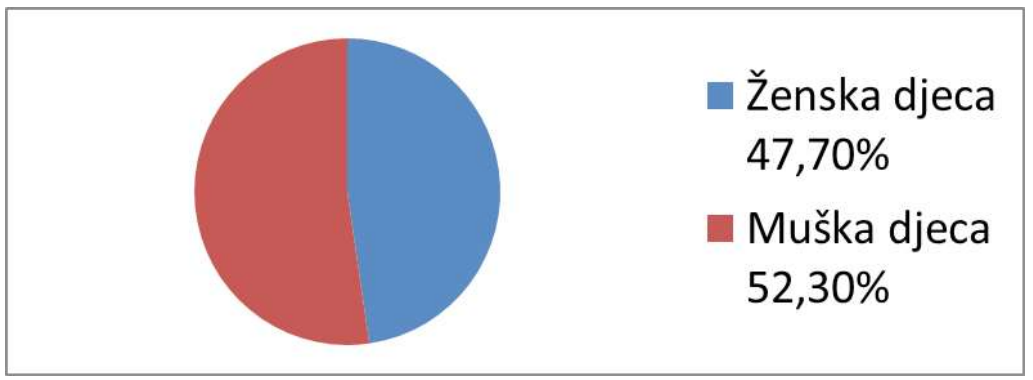

Grafikon 2. Rođenja od 1571. do 1596. u župi Cres

Usporedimo li navedene podatke za župu Cres s brojem od 1004 krštene djece u općini Lindar u razdoblju od 1592. do 1648. godine, vidimo da je u Lindaru rođeno 51,2 \% dječaka, to jest njih 514, dok je djevojčica bilo $48,8 \%$, ili njih $490 .{ }^{15}$ Pogledamo li podatke koji su dostupni za Tar u razdoblju od 1850. do 1880., rođeno je 1349 djece, od kojih je dječaka bilo 719 , tj. 53,3\%, dok je djevojčica bilo 630 , tj. 46,7 \%. ${ }^{16}$ U Tinjanu je u istom razdoblju kršteno 1586 djece, od čega $53,7 \%$ dječaka te $46,3 \%$ djevojčica. ${ }^{17}$ Podatci o omjeru rođenja muške i ženske djece pokazuju istu tendenciju za Cres, Lindar i Tar. Premda se ne radi o istim razdobljima, u njima se rađalo više muške nego ženske djece.

15 Danijela DOBLANOVIĆ, »Crtice o stanovništvu Lindara na kraju 16. i u prvoj polovici 17. stoljeća«, Vjesnik istarskog arhiva, br. 20 (2013.), str. 26, dostupno na: https://hrcak.srce.hr/121713 (pristupljeno 18. 6. 2020.).

16 Monika ZUPRIĆ, »Kćeri i sinovi Tara, Vabrige i Frate. Analiza matičnih knjiga krštenih župe Tar 1850. - 1880.«, u: isto, str. 66, dostupno na: https://hrcak.srce.hr/121716 (pristupljeno 20. 6. 2020.).

17 Lana KRVOPIĆ, »Matična knjiga krštenih župe Tinjan 1847. - 1880.«, u: isto, str. 41, dostupno na: https://hrcak.srce.hr/121714 (pristupljeno 24. 6. 2020.). 


\section{Mjesečni raspored rođenja}

Promatramo li odnos krštene djece po mjesecima, uviđa se kako je najviše djece kršteno, a prema tome i rođeno jer su se djeca najčešće krstila istoga dana kad su rođena ili tek koji dan kasnije, pri kraju ljetnih mjeseci: kolovoz (147 djece), rujan (146 djece), listopad (171 dijete). Ova su djeca začeta u razdoblju od studenoga do siječnja kada nastupa manji opseg poljoprivrednih radova ili, pak, dolazi kraj sezone radova. ${ }^{18} \mathrm{U}$ razdoblju od kolovoza do listopada prosječno je rođeno 154,6 djece. Najmanje je rođenja zabilježeno krajem proljeća i početkom ljeta - travanj (132 djece), svibanj (135 djece), lipanj (112 djece) te srpanj (99 djece). U navedenim mjesecima prosječno je rođeno 119,5 djece. Usporedimo li podatke s tarskom maticom koja obuhvaća razdoblje druge polovice 19. stoljeća, uviđamo kako je najviše rođene djece u ožujku - njih čak $11,27 \%$, a najmanje je rođenih u srpnju $(5,78 \%) .{ }^{19}$

\begin{tabular}{|l|c|c|c|}
\hline Mjesec & Ženska djeca & Muška djeca & Ukupno djece \\
\hline Siječanj & 75 & 75 & 150 \\
\hline Veljača & 66 & 72 & 138 \\
\hline Ožujak & 85 & 86 & 171 \\
\hline Travanj & 61 & 71 & 132 \\
\hline Svibanj & 59 & 76 & 135 \\
\hline Lipanj & 50 & 62 & 112 \\
\hline Srpanj & 46 & 53 & 99 \\
\hline Kolovoz & 71 & 76 & 147 \\
\hline Rujan & 75 & 71 & 146 \\
\hline Listopad & 75 & 96 & 171 \\
\hline Studeni & 65 & 84 & 149 \\
\hline Prosinac & 60 & 73 & 133 \\
\hline
\end{tabular}

Tablica 2. Prikaz rođene djece po mjesecima u župi Cres

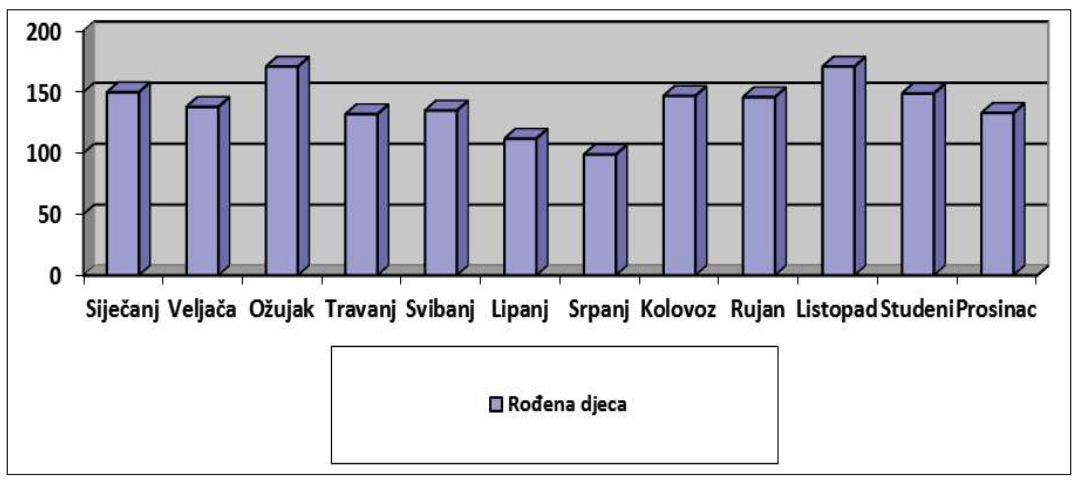

Grafikon 3. Prikaz rođene djece po mjesecima u župi Cres

18 Danijela DOBLANOVIĆ, »Sezonska kretanja začeća/rođenja župe Svetvinčenat u 18. stoljeću«, Povijesni prilozi, god. 31, br. 43 (2012.), str. 222.

19 ZUPRIĆ, »Kćeri i sinovi Tara...«, str. 75. 


\section{Začeća i sezonski poslovi}

Začeća su ovisila o mnogim čimbenicima. Prije svega o poljoprivrednim radovima koji su predstavljali izvor hrane, meteorološkoj situaciji, seksualnom porivu roditelja te društvenim i crkvenim normama ponašanja. ${ }^{20}$ Crkvene su se norme prvenstveno ravnale prema nastojanjima svećenstva na polju spasenja ljudske duše te stoga vođenja moralnoga života pa je u skladu s tim bilo zabranjeno sklapanje brakova u razdoblju posta i odricanja, odnosno korizme i došašća, a supružnicima je također sugerirano da se klone spolnih odnosa u vrijeme blagdana, nedjelja i osobito u vrijeme korizme i došašća. ${ }^{21}$

Analiza pregledanih dvadeset pet godina Matične knjige krštenih župe Cres pokazala je da je najviše začeća bilo krajem jeseni i početkom zime - u listopadu (147), studenom (147), prosincu (171) te siječnju (149). Najmanje je začeća bilo tijekom ljetnih mjeseci u lipnju (132), srpnju (135), kolovozu (113) te rujnu (99). Upravo je ovo ljetno razdoblje, vrijeme najmanjega broja začeća, ali i vrijeme kada se u ruralnim sredinama obavljaju sezonski poslovi - žetva, berba grožđa, maslina i ostalih prirodina. Premda je Cres bio urbano područje, njegovi su se stanovnici, poput stanovnika okolnih naselja, pretežito bavili poljodjelstvom. Stoga su na njihov način života i rada, pa tako i na spolne aktivnosti, uvelike utjecali i sezonski poslovi. Valja također naglasiti kako su i klimatske promjene igrale veoma važnu ulogu u reprodukciji otočana. U znanstvenoj se literaturi, primjerice, kao negativni čimbenici na polju reprodukcije navode visoke temperature i suha razdoblja pogodna za dnevne poljoprivredne poslove za vrijeme ljetnih mjeseci, dok se kišna ljetna razdoblja tretiraju kao pozivni čimbenici jer je stanovništvo ostajalo u svojim domovima pa je i seksualna aktivnost bila prisutnija. ${ }^{22} \mathrm{U}$ reprodukcijskom je ciklusu ulogu imala i Crkva koja je u razdobljima posta i odricanja nastojala zabraniti seksualne odnose među supružnicima. Nakon razdoblja zabrana i odricanja dolazilo bi do povećanja broja začeća, ali porast se broja začeća također može gledati i kao proljetno buđenje prirode i čovjeka, tj. njegova pojačanog spolnog nagona, a time i aktivnosti. ${ }^{23}$

Doblanović iznosi kako je u Lindaru najviše začete djece bilo u travnju i svibnju, a najmanji broj začetih bilježe kolovoz, rujan i listopad. To je objašnjeno završetkom crkvenih zabrana i početkom buđenja ljudske seksualnosti s obzirom na najveći broj začete djece, odnosno poljoprivrednim poslovima koji su se morali odraditi u kasno ljeto i ranu jesen s obzirom na najmanji broj začeća. Sukladno tome najviše je rođenih bilo u početnim mjesecima godine - siječnju i veljači, a najmanji je broj rođenih zabilježen u svibnju, lipnju

20 Zoran LADIĆ - Goran BUDEČ, »O nekim aspektima demografske, društvene i obiteljske povijesti Pićna u drugoj polovici 17. stoljeća prema matičnim knjigama krštenih (rođenih)«, u: Zbornik radova međunarodnog znanstvenog skupa održanog 23. i 24. listopada 2008., ur. Robert MATIJAŠIĆ - Elvis ORBANIĆ, DAPA, Pazin, 2012., str. 95.

21 Marija MOGOROVIĆ CRLJENKO, Nepoznati svijet istarskih žena, Srednja Europa, Zagreb, 2006., str. 60.

22 Peter T. ELLISON - Claudia R. VALEGGIA - Diana S. SHERRY, »Human birth seasonality«, u: $S e$ asonality in Primates: Implications for Human Evolution, ur. Diane K. BROCKMAN - Carel P. van SCHAIK, Cambridge Studies in Biological and Evolutionary Anthropology, Cambridge University Press, Cambridge 2005., str. 382, https://pdfs.semanticscholar.org/c7de/d789d54ca26b59fd932168249fdaa21 bc921.pdf (pristupljeno 21. 6. 2020.).

23DOBLANOVIĆ, „ Sezonska kretanja začeća/rođenja župe Svetvinčenat...«, str. 219. 
i srpnju. ${ }^{24}$ Prema podatcima koje donosi Vlahov za Boljun u periodu od 1600. do 1612. godine, vidljivo je kako je raspored začeća gotovo identičan onome u Lindaru. Najviše je začeća zabilježeno u travnju, svibnju te lipnju, dok je minimalan broj zabilježen u studenom i prosincu. ${ }^{25}$ Analiza matične knjige Umaga za razdoblje od 1593. do 1643. bilježi da je više djece začeto u prvim mjesecima godine te u razdoblju nakon korizme, tj. od travnja do lipnja. ${ }^{26}$ Tarska župa, doduše, u dosta kasnijem razdoblju, sredinom i drugoj polovici 19. stoljeća, bilježi najviše začetih u lipnju, a najmanje u listopadu, dok je u Tinjanu u drugoj polovici 19. st. također najveći broj začeća zabilježen u lipnju. ${ }^{27}$ Poreč u razdoblju od 1711. do 1800 . bilježi najmanje začetih u rujnu, ${ }^{28}$ a Buzet između 1870. i 1880. najmanje začetih bilježi u listopadu. ${ }^{29}$ Istraživanja Slavena Bertoše za razdoblje od 1613. do 1815. pokazuju kako je u Puli najviše začeća bilo u proljetnim mjesecima - ožujku, travnju i svibnju. ${ }^{30}$ Analiza Danijele Doblanović za župu Svetvičenat u 18. stoljeću pokazuje kako je najviše začeća zabilježeno u siječnju, veljači i ožujku. Nadalje, ona navodi kako broj začeća opada u ljetno vrijeme te svoj minimum bilježi u ranu jesen, u rujnu i listopadu. ${ }^{31}$ Takvi su podatci vrlo slični onima koje pronalazimo u creskoj matici. Zaključujemo kako neka od navedenih mjesta dijele slične minimume i maksimume po broju začeća u određenim mjesecima, međutim, neka se potpuno razlikuju (Cres i Lindar), što se može objasniti geografskim položajem (otok, kopno), poljoprivrednim poslovima i vremenskim uvjetima. U svim je spomenutim mjestima stanovništvo bilo pretežito katoličko te su za njega vrijedili crkveni propisi, prema kojima se u razdobljima posta i odricanja, odnosno došašća i korizme, nije podjeljivao blagoslov vjenčanja (osim u iznimnim slučajevima), a trebalo se suzdržavati i od spolnih odnosa. No lakše se moglo nadzirati sklapanje vjenčanja nego intimne odnose, za koje su od ključne važnosti bili način života i rada, a manje crkveni propisi. Stoga se i stanovništvo u svim mjestima nije podjednako pridržavalo tih propisa. ${ }^{32}$ No svim je tim mjestima zajedničko da su u ljetnim mjesecima bilježila najmanje začeća, što je moguće objasniti ljetnim vrućinama koje negativno utječu na intimne aktivnosti te poljoprivrednim poslovima koji su se morali odraditi kako bi stanovništvo imalo hrane u kasnijim mjesecima.

24 ISTA, »Crtice o stanovništvu Lindara...«, str. 29.

25 Dražen VLAHOV, Matična knjiga iz Boljuna: Glagoljski zapisi od 1576. do 1640, ser. Glagoljski rukopisi, knj. 9, DAPA, Pazin, 2011., str. 14.

26 DOBLANOVIĆ ŠURAN - MOGOROVIĆ CRLJENKO, Matična knjiga krštenih župe Umag..., str. 22.

27 ZUPRIĆ, »Kćeri i sinovi Tara...«, str. 75; KRVOPIĆ, »Matična knjiga krštenih župe Tinjan...«, str. $50-51$.

28 Egidio IVETIĆ, »La popolazione di Parenzo nel settecdento: aspetti, problemi ed episodi del movimento demografico«, Atti del Centro di ricerche storiche Rovigno, vol. XXI (1991.), str. 170-171.

29 Nenad VEKARIĆ - Božena VRANJEŠ-ŠOLJAN, »Početak demografske tranzicije u Hrvatskoj«, Anali Zavoda za povijesne znanosti Hrvatske akademije znanosti i umjetnosti u Dubrovniku, br. 47 (2009.), str. 42, dostupno na: https://hrcak.srce.hr/39107 (pristupljeno 21. 6. 2020.).

30 Slaven BERTOŠA, Život $i$ smrt u Puli-Starosjeditelji $i$ doseljenici od XVII. do XIX. stoljeća, Matica hrvatska, Ogranak Pazin, Pazin, 2002., str. 334.

31 DOBLANOVIĆ, »Sezonska kretanja začeća/rođenja župe Svetvinčenat...«, str. 225.

32 MOGOROVIĆ CRLJENKO, Nepoznati svijet istarskih žena..., str. 60-61. 


\begin{tabular}{|l|c|c|}
\hline Mjesec začetka & Broj začete djece & Postotak začeća \\
\hline Travanj & 138 & $8,17 \%$ \\
\hline Svibanj & 171 & $10,13 \%$ \\
\hline Lipanj & 132 & $7,81 \%$ \\
\hline Srpanj & 135 & $7,99 \%$ \\
\hline Kolovoz & 113 & $6,69 \%$ \\
\hline Rujan & 99 & $5,86 \%$ \\
\hline Listopad & 147 & $8,70 \%$ \\
\hline Studeni & 146 & $8,64 \%$ \\
\hline Prosinac & 171 & $10,13 \%$ \\
\hline Siječanj & 149 & $8,82 \%$ \\
\hline Veljača & 133 & $7,87 \%$ \\
\hline Ožujak & 150 & $8,88 \%$ \\
\hline
\end{tabular}

Tablica 3. Odnos začete djece po mjesecima u župi Cres

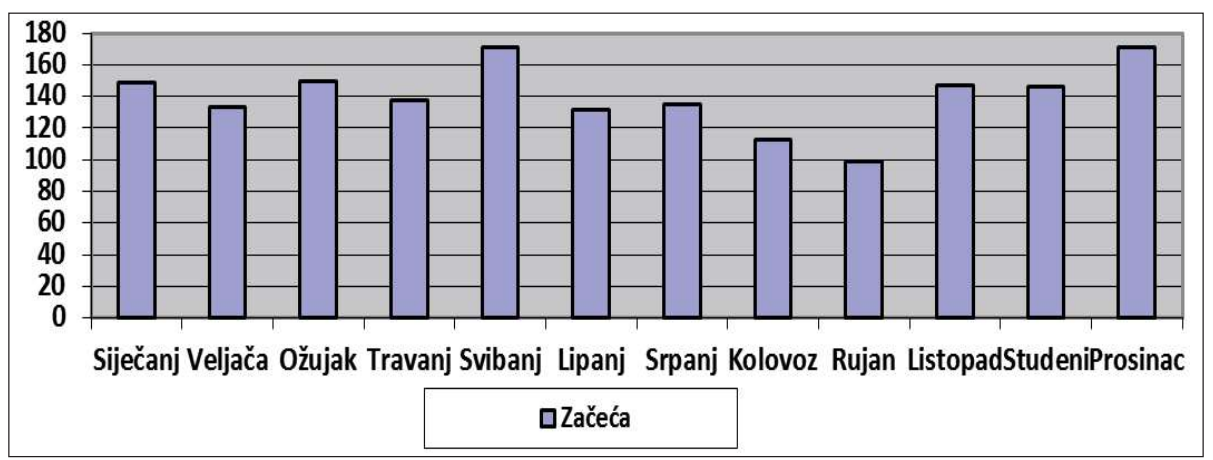

Grafikon 4. Prikaz začeća po mjesecima u župi Cres

\section{Svećenici i krštenja}

Već smo spomenuli da je Maticu pisalo mnoštvo svećenika (tridesetak). Oni su upisivali krštenja i pritom se notirali kao krstitelji. Ponekad su se upisivali punim imenom (Zuane Bochina Riccio), a ponekad skraćenim oblicima (Zuane Bochina, Zuane Riccio). U rukopisu nailazimo na mnoštvo kraćenja imena ili, pak, nedosljedna pisanja mahom obiteljskih imena ili pridjevaka (Michel Pecanich - Michel Pechacich; Mathio Bagatela - Mathio Bagatella - Mathio Bagathella; Andrea Antoniacio - Andrea Antoniazo; Andrea Drasa Piovano - Andrea Drasa - Andrea Piovano; Francesco Bochina-Francesco Buchina). Ponekad nailazimo samo na upisano osobno ime svećenika (Lodovicho - Lodovicho Zvonarich, Piovano) - ne možemo sa sigurnošću reći koji se svećenik tako potpisao jer je više njih obavljalo župničku službu, pa stoga uz svoje ime imaju zabilježenu i titulu piovano, odnosno župnik.

Donosimo abecedni popis svećenika koji su upisivali krštenike u Matičnu knjigu krštenih župe Cres u promatranom razdoblju od 1571. do 1596., s naznakom kad se radi o župni- 
cima jer je titulacija upisivana uz ime: Andrea Antoniacio, Andrea Bochina, Andrea Drasa Piovano, Antonio Bochina, Antonio Petris, Benetto Petris, Biasio Moscardin, Domenego Carlo, Francesco Bochina, Francesco Collumbis Piovano, Francesco Dragogna, Francesco Plescio, Gasparo Bochina, Gasparo Chicetta, Giovani Maria Atico, Jacomo Drasa Piovano, Jacomo Leon, Lodovicho Zvonarich, Mathio Bagathella, Mathio Staneo, Michael Cucletto, Michael Pechacich, Nicolò Creminea Primiceiro, Nicolò Rodinis, Simon Moysih, Zorzi Cledich, Zuane Fabris, Zuane Bochina Riccio, Zuane Juriacho i Zuane Vodarich.

Ovaj popis od trideset svećenika s jedne strane pokazuje koliko je bio bogat, osebujan i važan duhovni i sakralni život na otoku Cresu i u istoimenom gradu, a s druge strane i koliko je svećeničko zvanje bilo popularno, odnosno prihvatljivo kao temelj građenja karijere i egzistencije. Premještanjem vlasti iz Osora od oko 1450-ih dolazi i do postupnoga premještanja crkvenih ustanova u grad Cres. Seli se i biskupijska škola s kojom dolazi i do osnivanja kanoničkoga zbora. ${ }^{33}$ Iz navedenoga popisa uočava se kako su u promatranom razdoblju djelovala trojica župnika - Andrea Drasa Piovano, Francesco Collumbis Piovano i Jacomo Drasa Piovano. Benetto Petris se od upisa datiranoga 18. kolovoza počinje potpisivati titulom don, dok se Jacomo Drasa Piovano potpisuje kao don 27. veljače 1594. a Zuanne Bochina Riccio od početka se bilježenja knjige krštenih upisuje kao don. Titula upisana kod imena Francesca Plescia otkriva nam da je on u vrijeme upisa Archiadiacono di Osaro vicaro generale. Nicolò Creminea zabilježen je kao Primiceiro della cathedrall d' Orsaro što ukazuje na njegovu crkvenu poziciju. Za ostale svećenike koji nemaju oznaku titule ispred imena, možemo pretpostaviti da su bili pomoćnici župnika koji su dijelili i sakrament krštenja te ga upisivali u knjigu. Moguća je, dakle, pretpostavka kako je ovako velik broj klerika u gradu Cresu potaknut seljenjem biskupijske škole i kanoničkoga zbora te zbog gubljenja važnosti bivšega glavnoga grada otoka - Osora.

Andrea Antoniacio primjer je svećenika čije upise krštenja možemo pronaći u cijeloj knjizi. Isto vrijedi i za župnika (piovano) Jacoma Drasu. Andrea Antoniacio i Jacomo Drasa svećenici su koji su krstili najviše djece u promatranom periodu - obojica po 286. Zatim slijedi Gasparo Bochina sa 174 upisa, župnik Francesco Collumbis sa 139 upisa te Zuane Juriacho sa 103 upisa, dok ostali svećenici broje puno manje upisa od navedenih. Pri kraju Matične knjige uočili smo kako je župnik Jacomo Drasa obavljao više krštenja od ostalih premda se, primjerice, još uvijek pojavljuje i ime župnika Andree Antoniacia koji se, pak, učestalo kao krstitelj upisivao na početku Matice.

Slijedi abecedni prikaz tablice svećenika i broja njihovih upisa kako bi se prikazao odnos između svećenika i samih upisa u knjigu krštenih. Najviše upisa broje svećenicižupnici (piovano) što je vidljivo i iz tablice.

\begin{tabular}{|l|l|}
\hline Ime svećenika & Broj krštene djece \\
\hline Andrea Antoniacio & 286 \\
\hline Andrea Bochina & 1 \\
\hline Andrea Drasa Piovano & 12 \\
\hline Antonio Bochina & 18 \\
\hline
\end{tabular}

33 Biskupijska škola bila je namijenjena svoj muškoj djeci bez obzira na njihovu stalešku pripadnost; $u s p$. VLAHOVIĆ, Odlomci iz povijesti grada Cresa..., str. 34. 


\begin{tabular}{|l|l|}
\hline Antonio Petris & 8 \\
\hline Benetto Petris & 40 \\
\hline Biasio Moscardin & 69 \\
\hline Domenego Carlo & 2 \\
\hline Francesco Bochina & 4 \\
\hline Francesco Collumbis Piovano & 139 \\
\hline Francesco Dragogna & 8 \\
\hline Francesco Plescio & 1 \\
\hline Gasparo Bochina & 174 \\
\hline Gasparo Chicetta & 23 \\
\hline Giovani Maria Atico & 2 \\
\hline Jacomo Drasa Piovano & 286 \\
\hline Lodovicho Zvonarich & 30 \\
\hline Mathio Bagathella & 23 \\
\hline Mathio Staneo & 9 \\
\hline Michael Cucletto & 2 \\
\hline Michael Pechacich & 75 \\
\hline Nicolò Creminea Primiceiro & 1 \\
\hline Nicolò Rodinis & 5 \\
\hline Simon Moysih & 1 \\
\hline Zorzi Cledich & 7 \\
\hline Zuane Drasa & 1 \\
\hline Zuane Fabris & 6 \\
\hline Zuane Bochina Riccio & 18 \\
\hline Zuane Vodarich & 25 \\
\hline Zuane Juriacho & 103 \\
\hline Bezimeni svećenik & 4 \\
\hline
\end{tabular}

Tablica 4. Broj krštenja koje je obavio pojedini svećenik u župi Cres

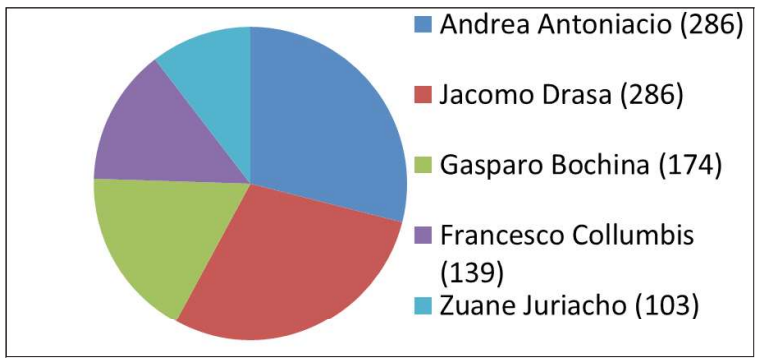

Grafikon 5. Broj krštenja po svećenicima u župi Cres

\section{Imena krštenika}

Promatrana creska matična knjiga pokazuje kako su djeci nadijevana jednočlana ili dvočlana imena, a višečlana imena nisu zabilježena. U ovom ćemo se poglavlju osvrnuti na nadijevanje muških i ženskih imena te motivaciju nadijevanja imena. 


\section{Muška imena}

Opseg muških imena u creskoj matici krštenih iznosi 75 različitih imena. Ponekad se jedno ime pisalo u više varijanti, kao npr. Bartholomio, Bartholomeo, Bartolomio, Bartolomeo; Dominicho, Dominico, Dumenigo, Dumenico... Od ukupnoga broja muške djece (883) njih 774 , to jest $87,65 \%$, ima dvočlano ime. Možemo zaključiti kako pri odabiru imena za mušku djecu dominiraju dvočlana imena. Creska matica ne donosi nam nijedan primjer krštenika kojem je nadjenuto tročlano ime. Umaška matica za razdoblje od kraja 15. stoljeća i do sredine 17. stoljeća bilježi $80 \%$ krštenika s dvama imenima, a vrlo rijetko one koji su imali tri ili više imena. Takve slučajeve u umaškoj matici D. Doblanović Šuran i M. Mogorović Crljenko povezuju s krštenicima iz uglednih obitelji. Od 702 krštenika njih 564, tj. 80,34 \%, ima dvostruko ime, a njih samo 18,54\% (130) ima jednostruko ime. Nadalje autorice navode kako se u promatranom razdoblju pojavljuje samo sedam upisa u kojima krštenik ima trostruko ime. ${ }^{34}$ Tarska, pak, matica za sredinu 19. st. donosi podatke o tome da 719 krštenih dječaka (76,08 \%) ima jedno ime, dok njih $22,5 \%$ imaju po dva imena, a samo 12 dječaka $(1,67 \%)$ ima po tri imena. ${ }^{35}$

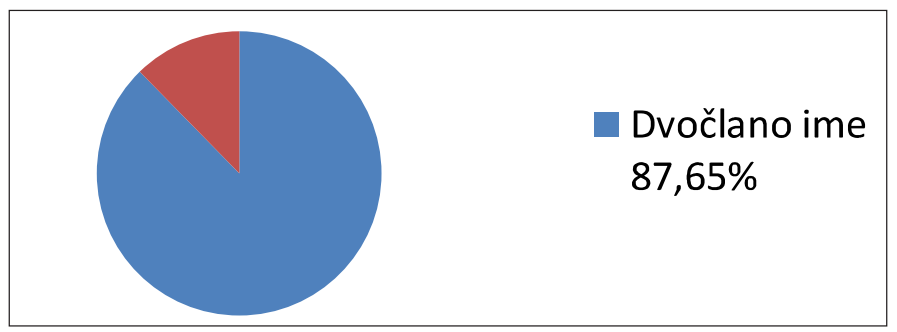

Grafikon 6. Odnos muških imena po sastavnicama

Najčešća prva imena, prema creskoj matici, nadijevana muškoj djeci na krštenju jesu: Zuane (136), Francesco (107), Nicolò (95), Antonio (67), Mathio (51), Jacomo (52), Piero (32), Andrea (31), Zorzi (31), Marco (22) i Stefano (22). Ostala imena koja se javljaju od dvadeset do samo četiri puta često su prisutna kršćanska imena i ona su: Gasparo (19), Dominicho (15), Bernardo (14), Jerolimo (14), Bartholomio (12), Filipo (9), Michel (8), Martin (7), Paulo (7), Valerio (7), Simon (7), Barthole (6), Julio (5) te Zanpiero (5). Ostala imena koja se u rukopisu pojavljuju od jednom do četiri puta nazvali smo rijetkim imenima te ih donosimo abecednim redom: Aquilano, Aurelio, Augustin, Arian, Beneto, Bernichio, Baldichio, Batista, Biasio, Costantin, Cesare, Chersichio, Christoforo, Coriollane, Cosmo, Donado, Damian, Drasio, Gabriel, Gaudentio, Giorgio, Gregorio, Iseppo, Isidoro, Justin, JuanMaria, Lelio, Lucian, Lodovicho, Lorenzo, Missaldo, Moyse, Natalle, Pasqualin, Roco, Rollan, Silvio, Thomaso, Tranquilio, Vido, Valentin, Ventura, Roco, ZanBaptista, ZanFrancesco, ZanJacomo, ZanMarco, ZanMaria, ZanPaolo, ZanZorzi te ZanJerolimo. U rukopisu je zabilježeno pet dječaka čija imena nisu upisana. Možemo pretpostaviti kako

34 DOBLANOVIĆ ŠURAN - MOGOROVIĆ CRLJENKO, Matična knjiga krštenih župe Umag..., str. 28. 35 ZUPRIĆ, »Kćeri i sinovi Tara...«, str. 76. 
je možda pri porodu došlo do komplikacija te je dijete rođeno mrtvo ili je neposredno prije krštenja ili na samom krštenju umrlo, pa se zbog toga ime izostavljalo. Moguće je također da je svećenik koji je upisivao krštenje jednostavno zaboravio upisati ime jer je podatak možda upisivao nekoliko dana nakon samoga krštenja. No nijednu od iznesenih pretpostavki ne možemo potvrditi.

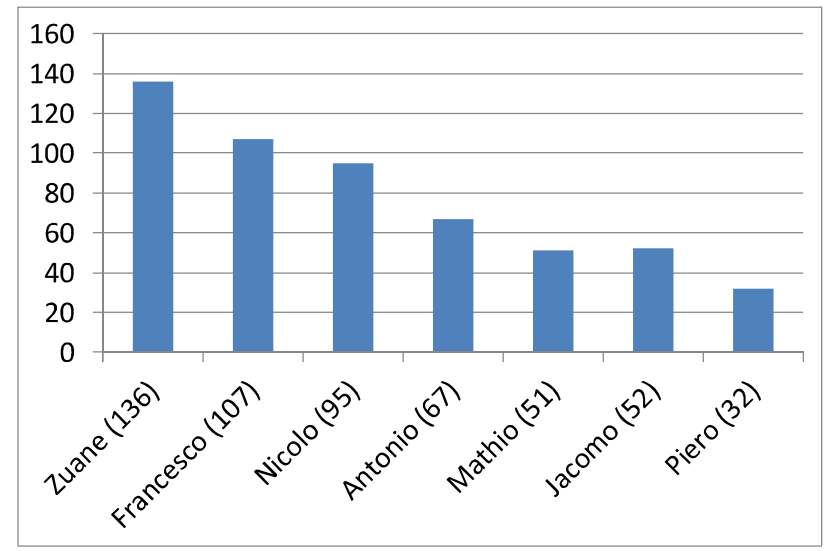

Grafikon 7. Najčešća prva muška imena u župi Cres

Matična knjiga župe Lindar broji puno manji opseg muških imena (38) te su mnoga imena nadahnuta katoličkim svetcima. ${ }^{36}$ Najčešće muško ime jest Ivan (Zuane) koje je dobilo $75 \%$ krštenika, dok je, primjerice, u župi Pićan isto to ime dobilo tek $12 \%$ dječaka. ${ }^{37}$ Zatim se od učestalijih imena spominju Mate, Juraj, Grgur, Martin, Mihovil, Andrija, Antun, Bartol i Petar. ${ }^{38}$ Među najpopularnijim imenima za krštenike umaška matica navodi imena Ivan, Petar, Frane, Matija, Juraj, Jakov, Anton, Dominik te Nikola. ${ }^{39}$

Usporedimo li podatke s creskom maticom, uviđamo kako su najučestalija imena dodjeljivana creskoj djeci bila: Zuane (15,40\%), Francesco (12,11\%), Nicolò (10,75 \%), Antonio (7,58), Mathio (5,77 \%), Jacomo (5,80\%), Piero (3,62 \%), Andrea (3,51\%) te Zorzi (3,51 \%). Popularno ime Francesco možemo dovesti u vezu s crkvom i samostanom sv. Franje izvan srednjovjekovnih zidina grada Cresa. Uočavamo kako su imena Franjo (Francesco) i Ivan (Zuane) među najpopularnijim imenima za muško dijete nevezano radi li se o prvom ili drugom imenu. Sv. Ivan Krstitelj slavi se 24. lipnja, Sv. Ivan Evanđelist 27. prosinca dok se Sv. Franjo slavi 4. listopada. Mali je broj krštenika rođen oko navedenih datuma da bi se moglo reći kako je datum rođenja bio motivacija za nadijevanje tih imena. Ime Nikola (Nicolò) možemo dovesti u vezu s istoimenom crkvom sv. Nikole, koja se nalazi na šetnici uz more te nije bila u sustavu gradskih zidina. Sv. Nikola slavi se 6. prosinca te je

36 DOBLANOVIĆ, »Crtice o stanovništvu Lindara...«, str. 31.

37 LADIĆ - BUDEČ, »O nekim aspektima demografske, društvene i obiteljske povijesti Pićna...«, str. 101.

38 DOBLANOVIĆ, »Crtice o stanovništvu Lindara...«, str. 33.

39 DOBLANOVIĆ ŠURAN - MOGOROVIĆ CRLJENKO, Matična knjiga krštenih župe Umag..., str. 28. 
zaštitnik ribara, pomoraca i djece. Možda se mogu povući paralele između poslova koji su obavljali roditelji ili je ime bilo motivirano zaštitom koja se pripisivala navedenom svetcu. No mali je broj djece rođen početkom prosinca kako bismo mogli tvrditi da je baš to bila motivacija za nadijevanje imena. Ime Bartolomej (Bartholomeo) također možemo povezati $\mathrm{s}$ istoimenom crkvom i bratovštinom na brdu pokraj naselja Merag, dok ime Dominik (Dominicho) možemo dovesti u vezu s nedjeljama te je lako moguće kako su pojedina djeca s ovim imenom rođena baš u nedjelju.

Analiza je pokazala da 107 djece, to jest njih 12,35 \%, nema drugo ime, a ovima smo pribrojili i onih pet dječaka čija imena nisu upisana. Najčešća imena koja su dječaci dobivali kao drugo ime na krštenju jesu: Bartholomeo (350), Francesco (57), Zuane (45), Antonio (30), Dominicho (28), Jacomo (26), Andrea (21), Mathio (18), Zorzi (16), Nicolò (13), Simon (10), Marco (10), Jeronimo (10), Gasparo (9), Piero (8), Stefan (7), Luca (7), Bernardin (7), Barthole (7), Martin (6), Thomaso (6), Michel (5) i Gregorio (5). Rijetka druga imena s manje od četiri upisa jesu: Anastasio, Augustin, Biasio, Baldisor, Baptista, Colarin (?), Christoforo, Federico, Fidel, Filipo, Gaudentio, GianGiorgi, Giorgi, Ipollito, Iseppo, Isidoro, JoanPiero, Julio, Lodovico, Lorenzo, Lucian, Maria, Mario, Mavro, Nadal, Paolo, Pasqualin, Roco, Salemon, Sebastian, Sigismondo, Sisto, Silvestro, Stanula, Thadeo, Thoma, Tiburcio, Vido te Vicencio. Ne možemo sa sigurnošću utvrditi zašto su neka djeca dobila drugo ime, a neka nisu. Pretpostavljamo kako je to ovisilo o volji roditelja, kumova ili, pak, o vremenu kad je dijete rođeno. Primjetno je kako je najviše muške djece dobilo kao drugo ime Bartholomeo, tj. njih 45,21\%. Već smo spomenuli da je na Cresu postojala crkvica posvećena sv. Bartolomeju na istoimenom brdu prije naselja Merag. Crkvica je sagrađena u 12./13. stoljeću te je bila središte istoimene bratovštine koja je ukinuta u 17. stoljeću. ${ }^{40}$ Možemo pretpostaviti kako su možda pripadnici bratovštine svojoj djeci davali ime ovoga svetca u znak zaštite ili kao oznaku pripadnosti samoj bratovštini. Svetac se slavi 24. kolovoza, a samo je $10 \%$ krštenika rođeno u kolovozu da se može dovesti u vezu sa slavljenjem Sv. Bartolomeja, dok je za ostale krštenike motiv nadijevanja toga imena očito bio drugačiji. Ostala česta druga imena krštenika jesu: Francesco (7,36 \%), Zuane (5,81 \%), Antonio (3,87\%), Dominicho (3,61 \%), Jacomo (3,85 \%), Andrea (2,71 \%), Mathio (2,32\%) te Zorzi (2,06\%).

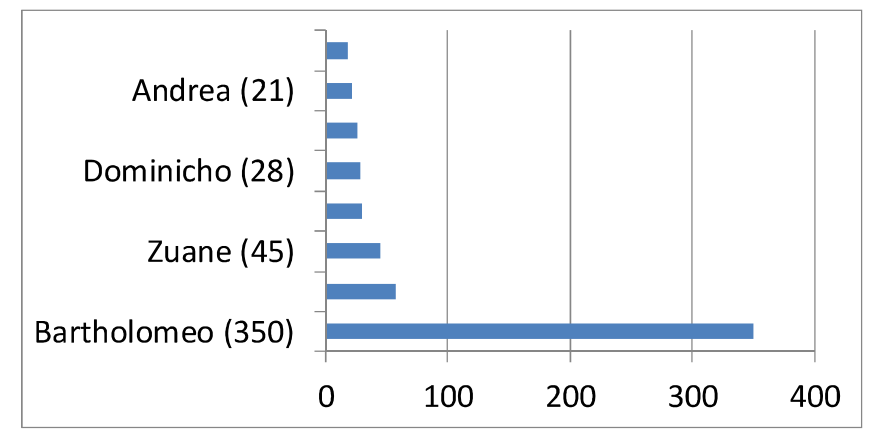

Grafikon 8. Najčešće drugo muško ime u župi Cres

40 SOLIS, Crkve i kapele cresko-lošinjskog arhipelaga..., str. 51. 


\section{Ženska imena}

Creska matica broji 80 različitih ženskih imena. Kako smo već naveli za muška imena, tako vrijedi i za ženska - neka su od njih imala više inačica, pisala su se na mnoge načine, što je uvelike ovisilo o svećeniku-pisaru. Primjerice: Catarina, Cattarina, Catharina, Catherina; Matea, Mathea, Matthea; Bartholomea, Bartholomia, Bartolomia, Bartolomea... Matica bilježi vrlo visok postotak $(88,81 \%)$ dvočlanoga imena nadijevanoga djevojčicama, međutim, ne nalazimo nijedno tročlano ili višečlano ime. Za usporedbu, umaška matica bilježi u ukupnom broju krštenih djevojčica (664) njih 84,48 \% (561) s dvočlanim i samo $15,52 \%$ (101) s jednostrukim imenom. Ta nam matica ne donosi podatke o tročlanim ženskim imenima. ${ }^{41}$ Analiza tarske matice iz polovice 19. stoljeća pokazuje da je od 630 djevojčica koje su krštene njih $68,41 \%$ imalo po jedno ime, njih $29,68 \%$ dvočlano te je samo njih $1,90 \%$ imalo tri imena. Ta matica broji 31 različito žensko ime. ${ }^{42}$

Najčešća su prva imena dodijeljena djevojčicama na krštenju u župi Cres bila: Maria (108), Catarina (100), Antonia (86), Francesca (71), Dominica (46), Zuana (35), Matea (28), Franica (19), Lucia (13), Magdalena (12), Petrica (12), Margarita (11), Pasqua (11), Doncha (9), Michela (9), Clara (7), Filipa (7), Joana (7), Orsolina (7), Paula (7), Andriana (6), Anzola (6), Chiara (6), Stefana (6), Elena (5), Isidora (5), Jacoma (5), Mathia (5) te Orsa (5). Najčešća su prva imena dodijeljena djevojčicama bila: Maria (13,41\%), Catarina $(12,42 \%)$, Antonia (10,68 \%), Francesca (8,81\%), Dominica (5,71\%), Zuana (4,34\%), Matea (3,47 \%), Franica (2,36 \%) te Lucia (1,61\%) - ostala se imena vode kao rijetka jer njihov postotak ne prelazi $1 \%$ krštenih djevojčica. U rijetka imena ubrajamo sva ona koja su djevojčice dobile na krštenju manje od četiri puta, to su: Agnia, Andrea, Angelica, Ana, Anthea, Apolonia, Barica, Bartholomea, Bernardina, Biasia, Camila, Cassandra, Cecilia, Cintia, Claudia, Contesa, Cornelia, Diana, Dobrica, Donata, Eufemia, Gaspara, Giana, Helizabet, Isabetta, Julia, Justina, Laona, Laura, Libera, Livia, Lodovica, Lucretia, Marieta, Mariza, Martina, Michulina, Nicola, Nicolosa, Orsola, Pasquina, Perina, Reggina, Sidra, Simona, Tharsia, Verdemina, Veronica, Vicenza i Vitta. Nalazimo osam upisa djevojčica bez zabilježenoga imena. Možemo pretpostaviti, kako smo spomenuli i kod bezimenih dječaka, da je možda pri porodu došlo do komplikacija te je dijete rođeno mrtvo ili je neposredno prije krštenja ili na samom krštenju umrlo pa se zbog toga ime izostavljalo ili, pak, svećenik jednostavno nije zabilježio ime ili ga je zaboravio, ako je naknadno upisivao u maticu. Ni ovdje također nije moguće sa sigurnošću utvrditi točnost nijedne od iznesenih tvrdnji.

Za usporedbu, lindarska župa u razdoblju od 1591. do 1667. godine bilježi raspon od 42 ženska imena što je gotovo dvostruko manje nego što smo ih našli u creskoj matici vođenoj u razdoblju od 1571. do 1596. U navedenom razdoblju creska matica broji 1688 upisa, dok lindarska matica u dužem razdoblju broji tek 1004 upisa, što je i shvatljivo jer je Lindar bilo manje mjesto. Kao najčešća ženska imena lindarske župe navode se: Katarina, Jelena, Eufemija, Margareta, Lucija, Matea, Ivana, Ursula, Magdalena te Martina. Popularnost

41 DOBLANOVIĆ ŠURAN - MOGOROVIĆ CRLJENKO, Matična knjiga krštenih župe Umag..., str. 50.

42 ZUPRIĆ, »Kćeri i sinovi Tara...«, str. 76. 


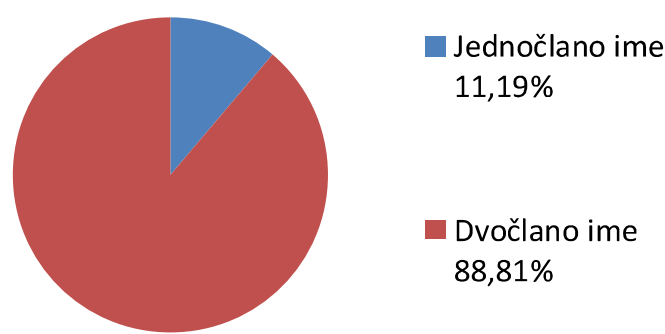

Grafikon 9. Odnos ženskih imena po sastavnicama

imena Katarina objašnjena je crkvom u blizini Lindara koja je posvećena sv. Katarini. ${ }^{43}$ U Pićnu su u drugoj polovici 17. stoljeća najčešća imena koja su se nadijevala djevojčicama bila: Ivana (Zuana), Margareta, Antonija, Marija i Katarina. ${ }^{44}$ Imena koja su najčešće nadijevana djevojčicama u Umagu od kraja 15. stoljeća pa do sredine 17. stoljeća jesu: Katarina, Lucija, Marina, Ivana, Elena, Antonija, Franciska, Marija i Margareta. ${ }^{45}$ Primjećujemo kako postoje ženska imena koja se pojavljuju i u Cresu, Lindaru, Pićnu i Umagu, a to su: Katarina, Marija, Antonia, Ivana (Zuanna), Matea, Magdalena te sva pripadaju kršćanskom svetačkom korpusu. U navedenim je mjestima primjetno da je najpopularnije ime Katarina. Imenovanje djevojčica ovim imenom može se povezati sa sv. Katarinom, zaštitnicom djevojaka, čiji se dan slavi 25. studenoga. Gledajući datume upisa djevojčica s imenom Katarina, samo se njih 7, tj. 7 \% može povezati sa slavljem sv. Katarine, dok je druga moguća motivacija za nadijevanje ovoga imena sama crkva Sv. Katarine u kojoj su možda te djevojčice bile krštene. Druge motivacije za nadijevanje ovoga imena nismo u mogućnosti sa sigurnošću utvrditi.

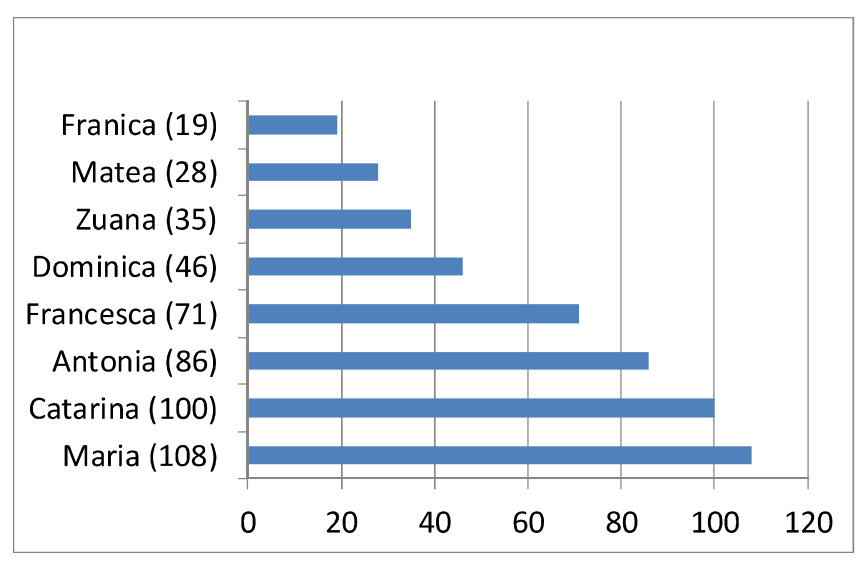

Grafikon 10. Najčešća prva ženska imena u župi Cres

43 DOBLANOVIĆ, »Crtice o stanovništvu Lindara...«, str. 31-33.

44 LADIĆ - BUDEČ, »O nekim aspektima demografske, društvene i obiteljske povijesti Pićna...«, str. 101.

45 DOBLANOVIĆ ŠURAN - MOGOROVIĆ CRLJENKO, Matična knjiga krštenih župe Umag..., str. 28. 
Dvočlano ime nosi $715, \mathrm{tj} .88,81 \%$ djevojčica, a među najčešćim se imenima izdvajaju sljedeća: Bartholomea (278), Franceschina (47), Maria (44), Antonia (37), Catarina (35), Dominica (32), Matea (19), Zuana (13), Orsola (12), Lucia (10), Margarita (10), Franica (7), Jacoma (6), Augustina (5), Nicolosa (5), Orsa (5), Pasqua (5) te Pasqualina (5). Ako najčešća imena izrazimo u postotcima, to izgleda ovako: Bartholomea 38,88 \%, Franceschina 6,57\%, Maria 6,15\%, Antonia 5,17 \%, Catarina 4,89\%, Dominica 4,47 \%, Matea 2,65\%, Zuana $1,81 \%$, Orsola 1,67\%, ostala imena pripadaju rijetkima jer njihov postotak nije veći od $1 \%$. Među rijetka druga imena ubrajamo: Ana, Anastasia, Andriana, Angelika, Anzola, Apolonia, Barbara, Barthola, Benegnuda, Bernardina, Biasia, Cecilia, Chersana, Chiara, Clara, Diana, Dobriza, Doncha, Dorothea, Eufemia, Filipa, Gaspara, Gregoria, Helena, Isidora, Jeronima, Joana, Julia, Justina, Laura, Libera, Luana, Luisa, Lutia, Magdalena, Marieta, Martina, Matthia, Michela, Nicholosa, Natalia, Nicolina, Paminicha, Paula, Petrisa, Sidra, Silvestra, Simona, Stana, Stefana, Tarsia, Thadea, Thomazia, Vaneta, Veronicha, Virginia, Vicenca i Vitta. Nailazimo na broj od 90, tj. 11,19\% djevojčica koje su bile krštene bez drugoga imena.

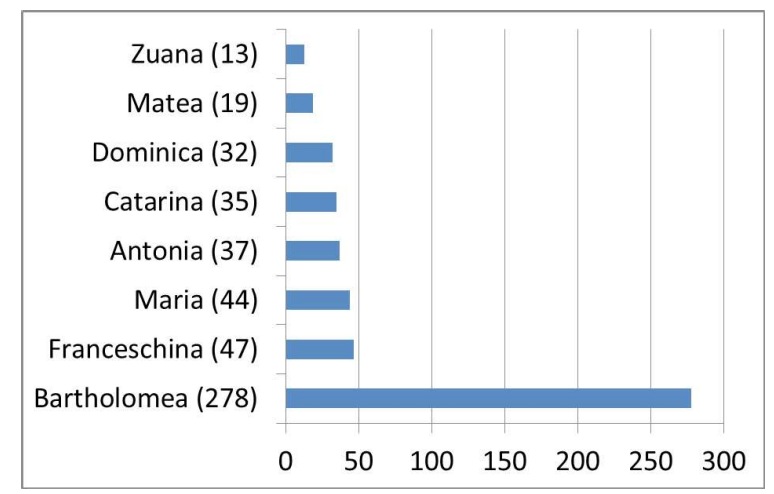

Grafikon 11. Najčešće drugo žensko ime u župi Cres

Primjetno je kako je i kod djevojčica u izboru drugoga imena najpopularnije isto ono kao i kod dječaka - Bartholomeo/Bartholomea. Opet nismo u mogućnosti sa sigurnošću utvrditi točan razlog popularnosti ovoga imena, osim što ga možemo dovesti u vezu s već spomenutom crkvom i bratovštinom sv. Bartolomeja. Od ukupnoga broja djevojčica koje su kao drugo ime dobile Bartholomea, samo se njih 32, tj. 11,65 \% rodilo u kolovozu, što ukazuje na vezu između rođenja i slavljenja toga svetca po kojemu je izvedeno i žensko ime. Imenovanje imenom Maria, koje se također često javlja kao drugo i najčešće kao prvo ime, možemo povezati sa župnom crkvom Gospe Snježne ili s nekim od blagdana na koji se slavi Blažena Djevica Marija. Blagdani prema kojima smo uspostavili vezu s nadijevanjem ovoga drugog imena jesu: 2. veljače - Prikazanje Gospodinovo, 25. ožujak - Navještenje, 31. svibnja - Pohođenje BDM, 5. kolovoza - Velika Gospa, 8. rujna - Rođenje BDM, 8. rujna - Rođenje Marijino te 7. listopada - Gospa od Krunice. Marijanski blagdani prema kojima su djevojčice dobivale imena izraženi u postotcima izgledaju ovako: Prikazanje 
Gospodinovo 11,36 \%, Navještenje 6,81 \%, Pohođenje BDM 13,63 \%, Gospa Snježna 9,09 $\%$, Rođenje Marijino 13,63 \% te Gospa od Krunice 4,54 \%. Prema datumima navedenih slavlja možemo tvrditi da je čak 26, tj. 59,09\% djevojčica svoje ime dobilo prema blagdanu posvećenom Blaženoj Djevici Mariji. Ostale djevojčice s ovim imenom možda možemo dovesti u vezu s krštenjem u župnoj crkvi Gospe Snježne, ali to nije moguće sa sigurnošću utvrditi. Za imena Dominika i Bartolomea vrijedi sve navedeno kod muških inačica ovih imena.

Iz creske matice krštenih za razdoblje od 1571. do 1596. možemo primijetiti da je određenom manjem broju djece nadijevano ime sv. Sidra/Izidora: 0,38 \% muškoj te 1,53 \% ženskoj djeci. U muškoj varijanti ime je glasilo Sidar, u ženskoj Sidra, dok je talijanska verzija bila Isidor/Isidora. U Matičnoj knjizi nailazimo na talijanski oblik Isidoro/Isidora, i u muškoj i u ženskoj verziji. Ime je davano i kao prvo i kao drugo ime. Hrvatska verzija istoga imena korištena je samo za djevojčice i u slučaju nadijevanja prvoga i drugog imena, dok u promatranom razdoblju nije zabilježen nijedan primjer da je dječak kršten imenom Sidar. U gradu se Cresu, kao što je već spomenuto, nalazi crkva sv. Izidora/Sidra, koja je smještena u samom središtu nekadašnje srednjovjekovne jezgre. ${ }^{46}$

\section{Pridjevci (prezimena) očeva krštenika}

U promatranom periodu teško je govoriti o prezimenima u današnjem značenju toga pojma. Ona još nisu bila ustaljena, odnosno uz ime je stajao pridjevak, koji je upućivao na očevo ime, zanimanje ili, pak, na mjesto odakle je osoba bila rodom. Neki su se od tih pridjevaka postupno ustalili i počeli funkcionirati kao prezimena, dok su neki jednostavno iščezli s određenom osobom, a sljedeća je generacija dobivala nove pridjevke. Uporabom pridjevaka može se lakše pratiti određene osobe u notarskim ispravama, matičnim knjigama te drugim dokumentima u kojima se dotične spominju. Sustav prezimena kakav danas poznajemo na ovim prostorima može se pratiti tek od masovne uporabe pridjevaka/ prezimena, tj. od 16. stoljeća. ${ }^{47}$ Radi lakšega i preciznijeg snalaženja koristit ćemo termin pridjevak koji bolje opisuje ime koje je tada slijedilo nakon osobnog imena.

Ukupan fond pridjevaka zabilježenih u promatranih dvadeset pet godina u Matičnoj knjizi župe Cres čini njih 344. Od ukupnoga su broja pridjevaka 322 jednočlana, dok su samo 22 pridjevka dvočlana. Prva je sastavnica dvostrukoga pridjevka najčešće ustaljeniji pridjevak, a drugu čini jedan od rjeđih. Primjer su takvih pridjevaka neka od navedenih: Calafa Cragnez, Craglich Lucasih, Craglich Maricich, Damiahnevich Peteh, Dubranich Zaporich, Gambaro Ciroico, Mlacovich Banic, Moscardin Chuchich, Prelcich Jugali... Rijetkim pridjevcima smatramo one koji su u analiziranoj Matičnoj knjizi krštenih zabilježeni kod krštenika, odnosno njihovih očeva u manje od pet upisa. Takvih je ukupno 105 pridjevaka, tj. 30,52 \%. Najčešći su pridjevci sljedeći: Drasa (61 upis), Petris (47 upisa),

46 SOLIS, Crkve i kapele cresko-lošinjskog arhipelaga..., str. 39.

47 Anđela FRANČIĆ - Maja MILOVAN, »Imena u najstarijoj umaškoj matičnoj knjizi«, u: DOBLANOVIĆ ŠURAN - MOGOROVIĆ CRLJENKO, Matična knjiga krštenih župe Umag..., str. 45. 
Bochina (32 upisa), Cocorin (27 upisa), Fucich (27 upisa), Moscardin (25 upisa), Damiagnevich (22 upisa), Colombis (22 upisa), Calafa (20 upisa).

Kako bi se stekao bolji uvid u mnogostruki spektar pridjevaka, ovdje ćemo ih navesti grupirajući ih u skupine s brojem upisa u kojima se pojavljuju u Matičnoj knjizi. Navedeni pridjevci su pridjevci krštenika, odnosno njihovih očeva.

\begin{tabular}{|l|l|}
\hline Broj upisa & Pridjevci \\
\hline 19 & Chuchich, Fericiol, Malabotich \\
\hline 17 & Polovich, Pozupich \\
\hline 16 & Castelanich, Dragognia \\
\hline 15 & Antoniazo, Gapich \\
\hline 13 & Carvin, Zidarich \\
\hline 12 & Bataglia, Cosaz, Moyse, Profici, Rodinis \\
\hline 10 & Coracina, Filinich, Zambeli, Zutinis, Zvonarich \\
\hline 9 & Cesarovich, Donatis, Gachina, Gelicich, Majerich, Medarich \\
\hline 8 & Bagatella, Fabro, Fornarich, Jurjaco, Rumbecich \\
\hline 7 & Carbolino, Ivancich, Lucaris, Lucis, Plecanich, Staneo, Susich \\
\hline 6 & $\begin{array}{l}\text { Bugarich, Ferlora, Gesmondin, Menchovich, Milanese, Petrinich, Rusanich, Segu- } \\
\text { glich, Sintich, Stosiich }\end{array}$ \\
\hline 5 & $\begin{array}{l}\text { Bolmarcich, Chledich, Craglich, Fiastro, Furlan, Ivagnusich, Lovrencich, Magerich, } \\
\text { Magnifico, Matusich, Mladostich, Negri, Sidrovich, Stefanin, Vahnich, Zicovich }\end{array}$ \\
\hline & $\begin{array}{l}\text { Adrario, Blaschovich, Caligder, Camalich, Carlo, Cemerinich, Chersevanich, Francho, } \\
\text { Grando, Maramanich, Marcaro, Marogich, Muran, Musich, Onuchlich, Pecacich, Re- } \\
\text { mer, Saladera, Scrabogna, Sinclovich, Sisich, Solis, Stepaninich, Tentor, Zubranich }\end{array}$ \\
\hline
\end{tabular}

Tablica 5. Najčešći pridjevci krštenika, odnosno njihovih očeva

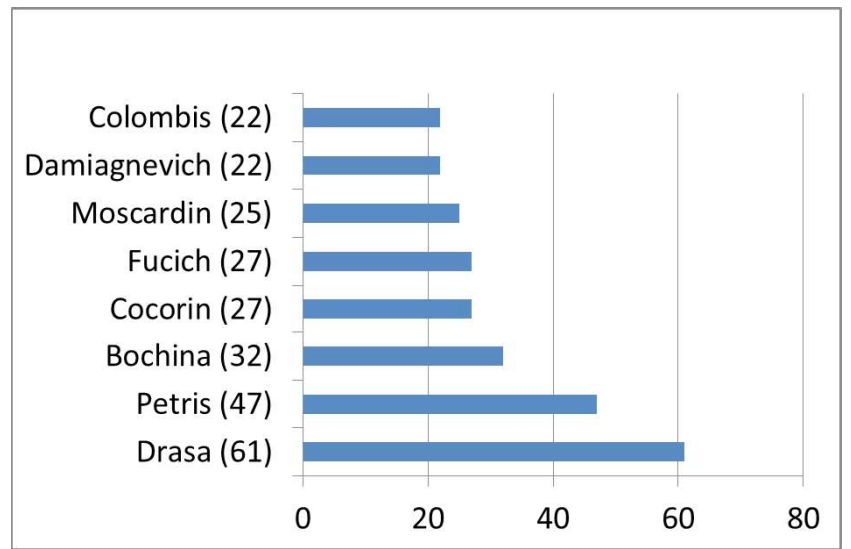

Grafikon 12. Najčešći pridjevci/prezimena očeva

U literaturi se kao creske plemićke obitelji navode sljedeće: Antoniazzo, Barba, Bruta, Bochina (Bokinić, Biochinich, Bocchina), Donatis (Donati), Drasa, Dragogna, Colombis (Golubić), Gapich (Capicio, Gapić), Filippo, Lepe, Moyse (Moisenić, Moise), Profici (Profaci), 
Perovich, Petris, Rodinis, Ursi i Zambeli. ${ }^{48}$ Neke su od njih bile aktivnije prije 16. stoljeća, neke su izumrle, dok su neke preživjele do današnjih dana s promijenjenim oblikom Petris - Petrić. Po prezimenima odnosno pridjevcima teško je utvrditi pripadnost nekoga čovjeka jer je upis njegova imena i prezimena ovisio o poznavanju talijanskoga jezika samog pisara, tj. svećenika, stoga nailazimo na različite varijante istoga pridjevka. Ovdje ćemo iznijeti samo ona prezimena odnosno pridjevke koji imaju najviše različitih inačica kako bismo pokazali da tada nije bilo jedinstvenoga načina zapisivanja jednoga pridjevka: Bataglia - Bataja - Bataglich - Bateglics - Battaglia-Battagia-Battaglich, Calafa-Callafa-Calaffa-Celafa-Challafarin, Choglievina - Chogljevina - Ghoglievina, Fuccich - Fucich - Fuch - Fucish - Fussics, Giarjacho - Giurglacho - Jurgacho - Juriacho - Jurjacho, Millanese - Milanese - Milanezich, Radoca-Radocca-Radocha. Iz navedenih primjera ponekad možemo vidjeti odakle je neko prezime, to jest je li se prezime latiniziralo, talijaniziralo ili kroatiziralo. No nekad nismo u mogućnosti iznijeti takve sudove jer nam to određena varijanta prezimena ne dopušta. Imamović navodi mletačka prezimena koja su bila u uporabi u Cresu: Querini, Bembo, Balbi, Dolfin, Corner, Lipomani, Morosini, Renier i Zorzi. Pojedina su prezimena do perioda koji promatramo jednostavno izumrla, dok su neka promijenila svoj oblik. Događalo se da u Cres dosele i plemići iz drugih mjesta, kao npr. s prostora Cipra, Terraferme ili, pak, s drugih prostora Mletačke Republike, odnosno ostatka otoka Cresa. Plemići koji su se doselili, primjerice, iz Osora, nisu smatrani plemićima dok ih nije potvrdilo cresko Gradsko vijeće. ${ }^{49}$ Pored upisa nekih od pridjevaka stoji kako je osoba koja ga nosi došla iz Venecije (Feri, Zorzi), Milana (Milanese), Padove (Padovani), dok se neka odnose na funkcije koje je određena osoba obavljala (Cavalieri). Za ostala prezimena/pridjevke nema jasne odrednice mjesta odakle su dolazila.

\section{Blizanci}

U promatranom razdoblju od dvadeset pet godina rođeno je 1688 djece, od kojih je bilo sedam parova blizanaca, to jest $0,829 \%$ blizanaca. Upisi u kojima su navedeni blizanački parovi koriste se frazom gemeli ili nati gemeli. Ne nalazimo vjenčani par s više od jednog para blizanaca. Od sedam parova - četiri su činili muško-muški par, što je 57,14 \%, dva su para bila s djevojčicama $(28,57 \%)$ te je jedan bio mješoviti par $(14,28 \%)$. U Pićnu je u razdoblju od 1664. do 1677 . zabilježeno čak $7 \%$ blizanaca $^{50}$ što je izuzetno velik postotak. Analiza Slavena Bertoše za Pulu u razdoblju od 1613. do 1817. pokazuje kako je ukupan broj upisanih blizanačkih parova $238, \mathrm{tj} .4,03 \%$, što je također poprilično velik postotak. Autor navodi kako od ukupnoga broja blizanačkih parova njih 40,16 \% otpada na muškomuške parove, 22,95 \% je žensko-ženskih parova, dok je mješovitih parova $31,97 \%{ }^{51}$

48 IMAMOVIĆ, Otoci Cres i Lošinj..., str. 88; VLAHOVIĆ, Odlomci iz povijesti grada Cresa...; vidi i: Nikša LUČIĆ, »Dvije obitelji iz Cresa«, Radovi Leksikografskog zavoda „Miroslav Krleža“, knj. 6 (1997.), str. 59-74.

49 VLAHOVIĆ, Odlomci iz povijesti grada Cresa.., str. 98.

50 LADIĆ - BUDEČ, »O nekim aspektima demografske, društvene i obiteljske povijesti Pićna...«, str. 99.

51 Slaven BERTOŠA, »Nati nel medesimo parto: slučajevi rođenja blizanaca u Puli - prema podacima iz novovjekovnih matičnih knjiga«, u: Filii, filiae...: Položaj $i$ uloga djece na jadranskom prostoru, Zbornik 4. istarskog povijesnog biennala, ur. Marija MOGOROVIĆ CRLJENKO, Zavičajni muzej Poreštine 
Tarska matica od 1850. do 1880. bilježi trinaest parova blizanaca, tj. 1,89 \%. ${ }^{52}$ Podatci za Buzet u periodu od 1870. do 1880 . navode $2,89 \%$ blizanaca. $^{53}$

Creska matica broji relativno malo rođenih blizanaca, međutim, teško je tvrditi koji je broj blizanačkih parova uopće i preživljavao. Dosadašnje analize, provedene za druga mjesta, pokazuju kako bi jedan od blizanaca, a moguće i oba, umro zbog komplikacija pri porodu, neodgovarajuće brige ili zimskoga vremena ako su tad rođeni. Ukoliko bi jednom od blizanaca prijetila smrtna opasnost, on/ona bio je kršten po hitnom postupku kako ne bi umro kao nekršten. ${ }^{54}$ Bertoša navodi kako je smrtnost $u$ dječjoj dobi bila vrlo visoka, čak $17,65 \%$ od ukupno krštene djece. ${ }^{55}$

Prvi blizanački par zabilježen u promatranoj Matici rođen je 30. svibnja 1577. od oca Antonia i majke Catarine. Imena rođenih dječaka su Filipo Zuane i Nicolò Bernardo. Godine 1580. rođena su dva para blizanaca. Dana 4. svibnja rođeni su Gasparo Bartholomea i Antonia Bartholomea od oca Gaspara Solisa i majke Marie. Drugi blizanački par rođen je 31. listopada od oca Mathia Filinicha i majke Matee - Cecilia i Jeronima. Već sljedeće godine, 29. srpnja, od oca Barthola Carvina i majke Zuane rođeni su Zuane Andrea i Roco Francesco. Nešto manje od pola godine kasnije rodio se još jedan par blizanaca, 26. siječnja 1582., Francesco Milcich i Mathea Tramontana dobili su Nicolu Bartholomea i Francesca Bartholomea. Sljedeći par rodio se 23. lipnja 1589., kada su Mathio Petrinich i Dminca postali roditeljima Nicoli Bartholomeu i Filipu Bartholomeu. Posljednji blizanački par u promatranom dvadesetogodišnjem razdoblju rođen je godinu kasnije, 14. ožujka 1590., djevojčice Antonia i Margarita od oca Zuanea i majke Catarine.

Primjećujemo kako šest od sedam parova blizanaca nosi po dva imena i da je većini blizanačke djece drugo ime bilo Bartholomeo/Bartholomea čiji se dan slavi 24. kolovoza,

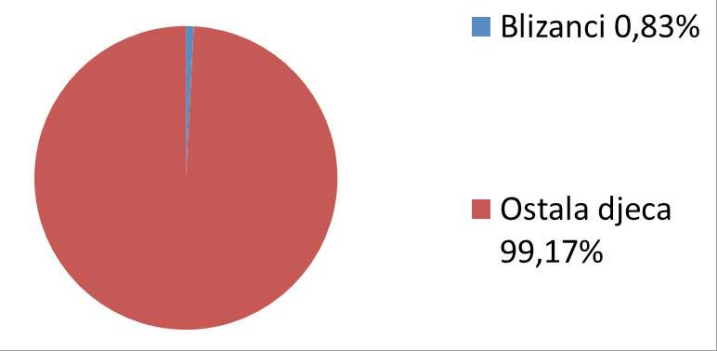

Grafikon 13. Odnos blizanačkih parova i ostale djece u župi Cres

/ Museo del territorio parentino - Odjel za humanističke znanosti Sveučilišta Jurja Dobrile u Puli DAPA, Poreč, 2011., str. 164. 
kako smo već spomenuli, a zaštitnik je proizvođača kože, cipela, oboljelih od kožnih i živčanih bolesti.

Grafikon 14. Omjer parova među blizancima u župi Cres

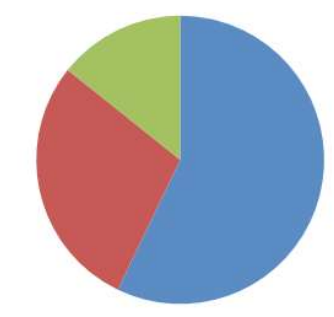

Muško-muški

par $57,14 \%$

Žensko-ženski

par $28,57 \%$

Mješoviti par

$14,28 \%$

\section{Kumovi}

Tridentski koncil, koji se održavao između 1545. i 1563. godine, propisao je obvezu sustavnoga vođenja matičnih knjiga vjenčanih i krštenih radi bolje evidencije kršćanskoga stanovništva, ali i nova pravila pri odabiru kumova na krštenju. Naime, prije Koncila bilo je sasvim prihvatljivo imati veći broj kumova na krštenju, međutim, nova su pravila propisala jednoga kuma i jednu kumu. ${ }^{56}$

Izbor kuma bio je važan jer je on bio odgovoran za duhovni odgoj krštenika, a sudjelovao je i u samom činu, odnosno obredu krštenja. Za kumove nisu mogli biti birani roditelji, čime se odvajala krvna/obiteljska veza od duhovne. Kumovi su prilikom krštenja postajali duhovni roditelji krštenika, a u slučaju smrti roditelja, krštenik bi bio povjeren kumovima na brigu. Nitko iz obitelji nije se mogao ženidbeno vezati za svoga kuma jer je samo kumstvo predstavljalo duhovnu sponu između te obitelji i kuma. Određeno je da osoba koja će postati nečijim kumom mora imati primljen sakrament krizme te određeni broj godina, koje se poklapaju s najnižom dopuštenom dobi za stupanje u brak, dakle, moraju biti punoljetni. Za dječake to je bilo 14 , dok je za djevojčice to bilo 12 godina. ${ }^{57}$

Već smo spomenuli da je u razdoblju od 1571. do 1596. u creskoj župi zabilježeno 1688 krštenja. Ukupno je na upisanim krštenjima bilo 1647 kuma te 2157 kumova. Najčešća struktura kumstva jest ona koju čine jedna osoba muškog spola, tj. kum i jedna osoba ženskog spola, tj. kuma - 70,8 \%. Postoje i žensko-ženska kumstva - 0,0017 \%, tj. samo dva upisa te muško-muška kumstva prisutna su u 29,1 \% upisa. Za usporedbu, D. Doblanović Šuran i M. Mogorović Crljenko, analizirajući umašku maticu, navode kako je u Umagu u

56 VLAHOVIĆ, Odlomci iz povijesti grada Cresa..., str. 98.

57 Danijela DOBLANOVIĆ ŠURAN - Marija MOGOROVIĆ CRLJENKO, »Kumovi na krštenju i svjedoci na vjenčanju u Istri od 15. do 17. stoljeća", Anali Zavoda za povijesne znanosti Hrvatske akademije znanosti i umjetnosti u Dubrovniku, vol. 56, br. 2 (2018.), str. 413-414. Usp i: Marija MOGOROVIĆ CRLJENKO - Danijela DOBLANOVIĆ, »Stanovništvo Rovinja prema najstarijoj matičnoj knjizi vjenčanih (1564. - 1640.)«, Povijesni prilozi, god. 34, br. 49 (2015.), str. 239-272, dostupno na: https://hrcak.srce. $\mathrm{hr} / 152678$ (pristupljeno 21. 6. 2020.). 
razdoblju od kraja 15. do sredine 17. st. bilo više muških kumova, i to u omjeru tri prema dva. Nadalje, autorice ističu kako su krštenici najčešće imali po dvoje ili troje kumova dok je zadnja navedena ženska osoba u upisu najvjerojatnije bila babica, koja se naziva velikom kumom (comadre maior). ${ }^{58}$ Tarska matica za drugu polovicu 19. st. daje slične podatke. Naime, prema njoj najčešći su kumovi bili muško-ženski parovi koji čine 83,02 \%, zatim slijede muško-muški parovi koji čine $2,59 \%$ te se navodi kako u analiziranom razdoblju od trideset godina nije bilo ni jednoga žensko-ženskog para. ${ }^{59}$

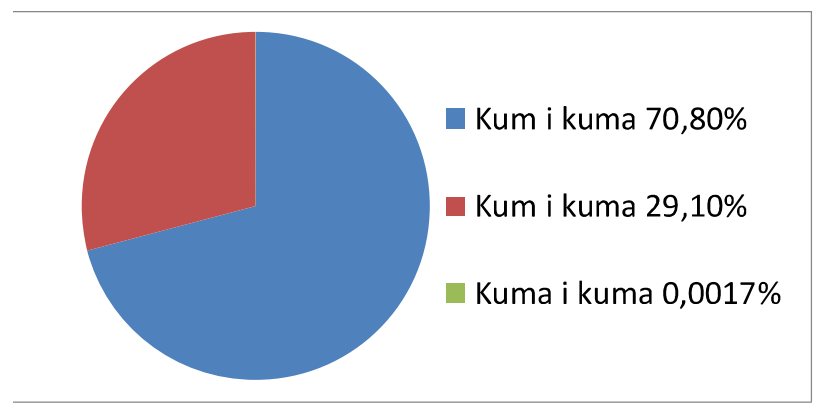

Grafikon 15. Omjer kumskih struktura

U promatranom dvadesetpetogodišnjem razdoblju u creskoj su matici najčešće zabilježena po dva kuma, kum i kuma. U 35 upisa $(2,07 \%)$ zabilježena su po tri kuma, u četiri upisa $(0,23 \%)$ zabilježena su po četiri kuma/kume, dok je jedan slučaj $(0,05 \%)$ s pet kumova/kuma. U navedenim upisima s po četiri i više kumova kumovi su pripadnici višega društvenog sloja što možemo iščitati iz njihovih titula signor, madonna, cavalier, capitano, contessa itd... Neuobičajen, odnosno veći broj kumova na pojednim krštenjima upućuje na to da je i sam krštenik pripadao obitelji višega društvenog sloja.

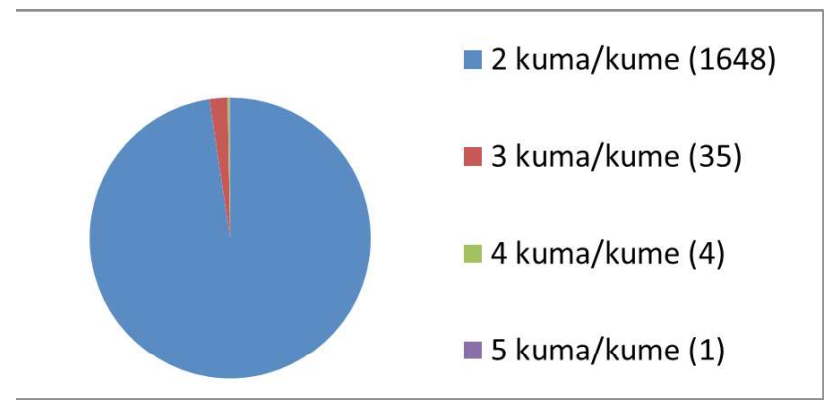

Grafikon 16. Omjer kumskih struktura 2

Kao prvi kum na krštenju najčešće je upisana muška osoba, i to u $99 \%$ upisa. Nailazimo također na dva slučaja bez ijednoga upisanog kuma. U svojstvu drugoga kuma najčešće su žene koje su na to mjesto upisane 1138 puta što iznosi 67,6 \%. Bilježimo 76 upisa bez

58 DOBLANOVIĆ ŠURAN - MOGOROVIĆ CRLJENKO, Matična knjiga krštenih župe Umag..., str. 24.

59 ZUPRIĆ, »Kćeri i sinovi Tara...«, str. 78. 
upisanoga drugog kuma, što iznosi $0,04 \%$. Matična knjiga broji 35 upisa s tri kuma. Za trećega kuma nešto su se više birale žene - 18 puta, tj. $52 \%$, dok su muškarci birani u 17 slučajeva, to jest $48 \%$. U primjerima u kojima su zabilježena po četiri kuma, a takva su četiri upisa, bilo je $50 \%$ muških i 50\% ženskih kumova odnosno kuma. Primjerice, dana 1. ožujka 1581. kršten je Stefan Bartholomio, sin misera Petrisa Petrisa i majke madone Chersane Petris. Kumovi su mu bili signor Marco i signor Piero, sinovi svijetloga signora Fedrica Molina conte-capitana Cresa i Osora, te signor Giulian Bressan i misero Renolfo Galasso ${ }^{60}$ Koliko je velik društveni utjecaj imao dotični Petris Petris u gradu, vidimo po ugledu koji su uživali kumovi - dva su kuma bila sinovi kneza kapetana (conte-capitano) Cresa i Osora, to jest osobe u čijim je rukama bila sva vlast na otoku. Drugi se primjer dogodio 31. srpnja 1582. na krštenju Zanjacoma Bartholomia kojemu su kumovi bili misero Francescho Chiucho, misero Hettore Cicutta, misero Jseppo iz Galla i misero Jacometto. ${ }^{61}$ Treći se dogodio 29. studenoga 1575. kad je kršten Valerio Martin, sin misera Zuanea Dabatte, kavaljera (cavalier) signora Marca Veniora, kneza-kapetana (conte-capitana), i majke Hellene Palaciole, a kumovi su bili plemeniti miser Hijeronimo, miser Zuane, kavaljer plemenitoga misera Hijeronima Zonche, potom miser Ruberto iz Venecije i svjedokinja Marcia, žena misera Bronora. ${ }^{62}$

Don Zuanne Riccio Bochina krstio je 9. rujna 1590. Nicoloa Jacoma, sina Francesca Drase, pokojnoga misera Jacoma i madone Benegnude, a kumovi su bili poštovani signor Giulio Vaneti, liječnik (medico), signor Giustinian Avoltori, Giulian Bresciano, te kume: madona Catarina, kći pokojnoga misera Cristofora Riccia Bochine, i Hierolima, kći misera Jacoma Fericciola.$^{63}$ Navedeni je primjer jedini u Matičnoj knjizi župe Cres koji broji pet kumova na krštenju, to jest tri kuma i dvije kume.

Za prvoga su kuma najčešće birani: Francesco Zambeli (83), Giulio Vaneti (50), Zuane Feri (42), Andrea Petris (31), Andrian Bochina (29), Checho Zambeli (28), Gierolimo Garzadore (23), Santin Zambeli (22 puta). Primjetno je da su se najčešće za kumove birali članovi obitelji Zambelli.

Giulio Vaneti bio je doktor, tako da njegov prvi izbor za kuma može značiti da je porod bio problematičan ili da dijete zahtijeva dodatnu brigu, premda nije moguće odrediti točnost nijedne pretpostavljene činjenice. Andrian Bochina neko je vrijeme obnašao dužnost

$60 \gg$ Io pre Jacomo Drasa batizai Stefano et Bartholomio fiol de misero Petris de Petris sua moglie madona Chersana Petris, compari il signor Marco et signor Piero fioli del clarissimo signor Fedrico Molin conte et capitano di Cherso et Ossero, et il signor Giulian Bressan, et misero Renolfo Galasso.«

61 »Io pre Gasparo Bochina battizai ZanJacomo et Bartholomio fiol de misero Nicolò Pavia sua moglie madona Paola compare misero Francesco Chiucho, et misero Hettore Cicutta, et misero Jseppo dal Gallo, et misero Jacometto."

$62 »$ Io Francesco de Columbis Piovano baptizai Valerio et Martin fiol de misero Zuane Dabatto cavalier del clarissimo signor Marco Venior conte, et capitano et sua moglie Hellena Palaciola, Compari il magnifico misero Hijeronimo fiol del sopra ditto clarissimo et misero zuane cavalier del clarissimo misero Hijeronimo Zoncha, misero Ruberto da Venesia, et comare, Marcia moglie de misero Bronoro."

63

»Io Don Zuanne Riccio de Bochine batizai Nicolò et Jacomo figliol di misero Francesco Drasa quondam misero Jacomo, sua moglie Madona Benegnuda. Compari il ecelente signor Giulio Vaneti, Medico, et il signor Giustinian Avoltori, Giulian Bresciano; Comare: Madona Catarina figliola quondam misero Crisoforo Riccio de Bochina et Hierolima figliola de miero Jacomo Fericciolo.« 
kavaljera (cavalier), što se vjerojatno s obzirom na značaj te službe odrazilo i na povećan broj sugrađana zainteresiranih za to da ga izaberu za krsnoga kuma. O Zuani Feriju jedino što možemo saznati iz Matične knjige jest da je bio iz Venecije, a na temelju toga ne možemo sa sigurnošću reći zašto je biran za kuma tako često. Važno je također napomenuti kako su mnogi stanovnici otoka dijelili ime i pridjevak/prezime, poput: Francesco Bochina od oca Donada Bochine bio je biran za kuma 21 put, dok je Francesco Bochina od oca Marca Bochine biran 16 puta za kuma. Nailazimo na još 11 upisa u kojima je kao prvi kum naveden Francesco Bochina, ali se ne može sa sigurnošću reći koji je od navedene dvojice bio posrijedi ili je, pak, postojao još koji Francesco Bochina.

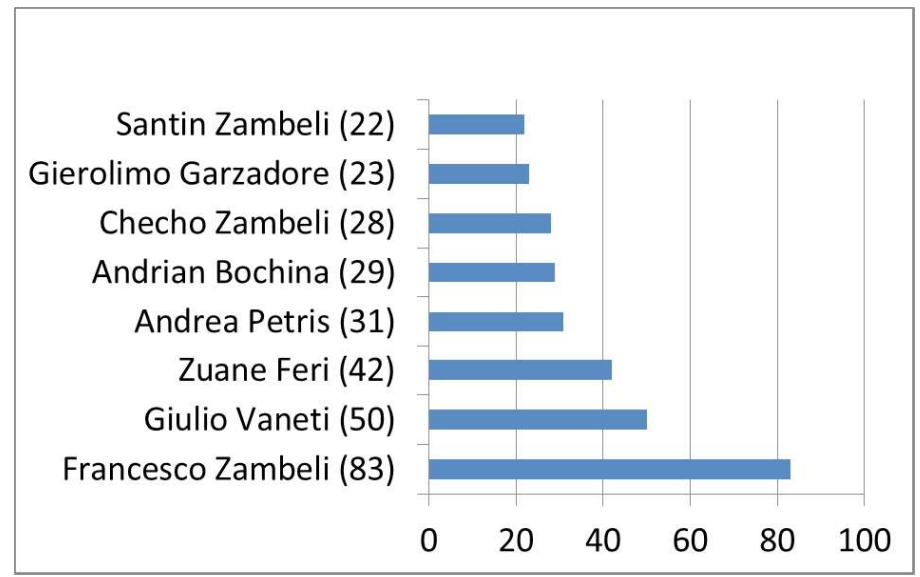

Grafikon 17. Najčešće birani prvi muški kum

Kako smo već naveli, za drugoga su se kuma na krštenju u većoj mjeri birale ženske, a ne muške osobe. Najčešće ženske osobe koje su birane za kume na krštenju jesu: Maria, kći Marca Bochine (23), Paula, žena Andree Saraguglicha (21), Antonia, kći Francesca Bochine (21), Maria, kći Nicole Petrisa (19), Antonia, kći Nicole Petrisa (18), Hierolima, kći Jacoma Fericiola (17), Michela, kći Stefana Petrisa (17) te Chiara, žena Andree Petrisa (16). Primjetno je kako su se često za kume na krštenju birale ženske pripadnice obitelji Petris, a tek onda u manjoj mjeri pripadnice drugih obitelji - Bochina i Fericiol. Cintia, žena Gierolima Gardazorea, birana je 11 puta za kumu na krštenju, isto kao i njen suprug te sluškinja - njih su dvoje najvjerojatnije predstavnici bogatijega sloja građanstva uz koje su se mnogi htjeli vezati kumskim vezama. Sluškinja je birana manje puta za kumu nego njena gospodarica, ali je moguće da su se određeni ljudi željeli, makar i preko sluškinje, vezati uz određenu obitelj. Najčešći izbor muških osoba za drugoga kuma bilježe: Gasparo Gambaro, doktor (18), Francesco Zambeli (13), Renolfo Gallaso (10), Zuane Feri i Zuane Pergolato Spicier (9), Julio Vaneti, doktor (8), te Andrea Petris i Checho Zambeli (7). Vidljivo je da su za kumove često birani liječnici (Gasparo Gambaro i Julio Vaneti), međutim, nije moguće sa sigurnošću tvrditi jesu li birani zbog teškoća pri porodu i brige za novorođenče ili zbog statusa koji nosi doktorska titula. 


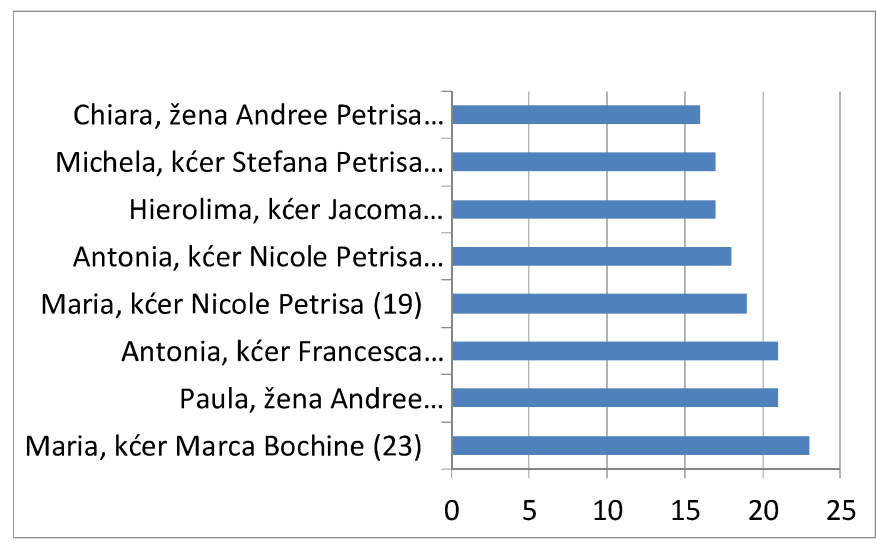

Grafikon 18. Najčešći izbor ženskih kuma

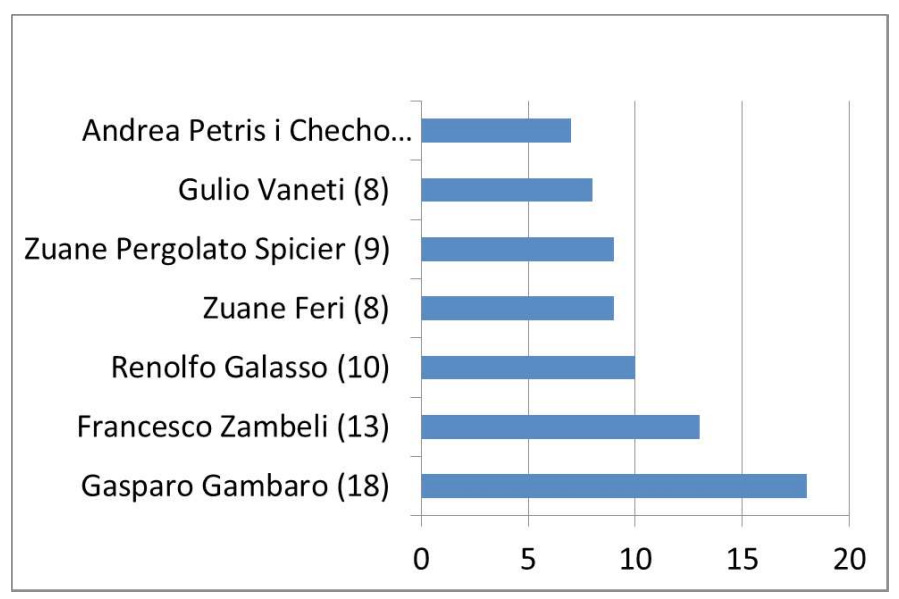

Grafikon 19. Najčešći izbor za drugoga muškog kuma

Kao treći kum na krštenju među muškim osobama ističe se Julian Bressan kojeg smo već ranije spomenuli pri krštenju s pet kumova, a među ženskim osobama Chiara Petris, žena Andree Petrisa. Iznijetu premisu o češćem biranju povlaštenoga sloja ljudi donosi nam i analiza umaške matice za razdoblje od 1483. do 1499. Iz nje vidimo da su u Umagu većinom birani obrtnici i ljudi raznih profesija (cavalier, conte-capitano, magister, advocato, medico...), zatim oni koji su uz ime nosili titulu, koja pokazuje njihov viši položaj u društvu (signor, euelente...) te svećenici. ${ }^{64}$ Creska matica broji vrlo malo upisa u kojima su kumovi svećenici. U takvim slučajevima većinom nema drugih kumova ili je prisutna bila samo kuma.

64 DOBLANOVIĆ ŠURAN - MOGOROVIĆ CRLJENKO, Matična knjiga krštenih župe Umag..., str. 26. 


\section{Zaključak}

Analiza Matice krštenih župe Cres za razdoblje od 1571. do 1596. pokazuje kako je na otoku bujao život, premda otočni položaj donekle pridonosi ograničenosti i zatvorenosti. Gradom Cresom i otokom vladala je Republika Svetog Marka koja je onamo slala svoje predstavnike vlasti. Knezovi-kapetani predstavljali su svjetovnu vlast uz cresko Gradsko vijeće. U Gradsko vijeće primali su se plemeniti građani i vrlo je rijetko Vijeće primalo nove članove.

Velik broj svećenika koji je sudjelovao u pisanju Matične knjige između ostaloga svjedoči i o tome kako je grad Cres nakon gospodarskoga, društvenog i crkvenog propadanja Osora dobio na važnosti. U grad su se preselile svjetovne i crkvene vlasti, što je dodatno osnažilo njegov značaj središnjega otočnog mjesta, a posljedično i do njegova gospodarskoga jačanja.

Religioznost ove otočke zajednice očituje se, između ostaloga, i u izboru svetačkih imena koja su djeci nadijevana, neovisno o tome je li se radilo o muškim ili ženskim imenima. S druge pak strane, analiza je pokazala kako su gospodarske aktivnosti, klimatske promjene te godišnja doba bitno više od crkvenih normi utjecala na seksualni život stanovnika otoka, a time i na začeća i rođenja. Primjetno je kako je u vrijeme gospodarskih aktivnosti bilo najmanje začeća. Navedeni su se poslovi obavljali od početka ljeta do jeseni. Najviše se začeća bilježi, dakle, u zimskim mjesecima kada je stanovništvo zbog vremenskih uvjeta ostajalo kod kuće i bilo manje zaposleno.

Primjetno je kako je najviše djece pri krštenju dobivalo dva imena i malo je djece koja su imala samo jedno ime. Matica donosi i upise krštenika bez imena za koje nismo u mogućnosti utvrditi razloge njihova izostanka. Najčešća muška imena krštenika bila su: Zuanne, Francesco, Nicolò, Antonio, Mathio, Jacomo, Piero, Andrea i Zorzi. Najčešća imena dodijeljena djevojčicama na krštenju bila su: Maria, Catarina, Antonia, Francesca, Dominica, Zuana, Matea, Franica te Lucia. Od ukupnoga broja krštene djece u razdoblju od 1571. do 1596. najmanje je blizančkih parova, na koje otpada $0,829 \%$. Najviše je bilo muško-muških blizanačkih parova, zatim slijede mješoviti parovi. Na temelju podataka iz Matice nije moguće utvrditi jesu li oba blizanca preživjela dječju dob jer je tada bila izrazito velika smrtnost.

Prezimena se, kao što smo već naveli, u promatranom razdoblju tek formiraju. Do masovnije uporabe prezimena dolazi u sljedećim stoljećima te se za promatrano razdoblje bolje služiti terminom pridjevak. On pobliže označava odakle dolazi određena osoba, kojeg je zanimanja ili kako joj se otac zvao. Navedene će se oznake u kasnijim stoljećima ustaliti te postati prezimenima. Mnogi pridjevci/prezimena creskih obitelji nisu preživjeli do današnjih dana, međutim, ima pridjevaka koji su se s vremenom mijenjali i održali do današnjih dana, npr. Petris - Petrić.

Važnu ulogu u životu krštenika imali su kumovi, koji su pažljivo birani. Njihova je uloga bila duhovna briga o tome da krštenik izrasta u moralnoga kršćanina. Neki od uglednijih građana češće su od drugih birani za kumove. Češće su, također, birani pripadnici 
imućnijega sloja, obrtnici, doktori i odvjetnici. Kumove su uglavnom činili muško-ženski parovi, dok su samo krštenici bogatijega sloja imali više od dva kuma.

U radu smo nastojali analizirati i ponuditi odgovore na određena pitanja u svezi sa začećem i rađanjem, postotkom muške i ženske djece, blizancima, nadijevanjem imena, postojanjem pridjevaka/prezimena, odabirom kumova te dobivene rezultate usporediti s postojećim analizama za pojedina istarska mjesta. Osim toga, istraživanje je otvorilo i određena pitanja na koja nije moguće odgovoriti samo analizom matica krštenih, već je za njih potrebna analiza ostalih matica (vjenčanih i umrlih), kao i sviju dostupnih pisanih izvora toga razdoblja povijesti župe Cres. Nadamo da će ovo naše početno istraživanje potaknuti nova istraživanja Cresa i creskoga stanovništva. 


\section{SAŽETAK}

\section{Matična knjiga krštenih župe Cres (1571. - 1596.)}

Rad je nastao na temelju istraživanja i analize najstarije sačuvane Matične knjige krštenih župe Cres. Pisala su je u razdoblju od 1571. do 1596. godine čak tridesetorica svećenika. Svaki je svećenik, što je i sasvim razumljivo, imao poseban stil pisanja i različit način oblikovanja slova, pa je rad na njoj predstavljao i svojevrstan paleografski izazov. Matica je pisana talijanskim jezikom, odnosno mletačkim dijalektom, koji je bio svojstven urbanim središtima otoka Cresa zbog gotovo kontinuirane nazočnosti mletačke vlasti od 1145 . do 1797. godine, kada je Mletačka Republika prestala postojati.

U radu je pružen tek kratak analitički osvrt na rukopise svećenika u Matičnoj knjizi krštenih župe Cres, nakon čega slijede poglavlja s podrobnijim raščlambama i predstavljanjima rezultata u svezi s godišnjim i mjesečnim rasporedom rađanja djece, potom u svezi s mjesečnim rasporedom začeća te vezom začeća sa sezonskim poslovima. U posebnim su se poglavljima pružili i osvrti na broj i ulogu svećenika krstitelja, na nadijevanje imena krštenicima, a predstavila su se i (naj)češća te nešto rjeđa muška i ženska osobna imena. Isto su tako obrađeni i pridjevci (prezimena) krštenika i njihovih očeva. U kratku je poglavlju analiziran i broj upisa koji se odnosi na blizanačke parove, a koji su bili vrlo rijetki u župi Cres u promatranom razdoblju. Rad završava nešto detaljnijim poglavljem u kojemu je objašnjena uloga kumova, ne samo u životu krštenika nego i u životu obitelji kojoj je pripadao krštenik. Istaknuta je i važnost broja kumova/kuma te (naj)češće biranih krsnih kumova/kuma u creskoj gradskoj zajednici.

Kako je riječ o prvom povijesno-demografskom uratku temeljenom na jednoj od matičnih knjiga otoka Cresa, komparativan je pristup sa sličnim istraživanjima i objavljenim rezultatima morao biti okrenut onima koje su odradili stručnjaci u susjednoj Istri. Riječ je o (polu)urbanim zajednicama, odnosno župama u Lindaru, Pićnu, Puli, Rovinju, Svetvinčentu, Umagu, Taru i Tinjanu. 


\section{SUMMARY}

\section{The Register of Baptisms of the Parish of Cres (1571 - 1596)}

The paper is based on the research and analysis of the oldest preserved Register of Baptisms of the Parish of Cres. It was written in the period from 1571 to 1596 by as many as thirty priests. Each priest, which is quite understandable, had a special style of writing and a different way of formatting the letters, which made working on it a kind of palaeographic challenge. The Register was written in the Italian language, i.e. the Venetian dialect, which was characteristic of the urban centres of the island of Cres due to the almost continuous presence of Venetian rule from 1145 to 1797, when the Venetian Republic ceased to exist.

The paper provides only a brief analytical review of the manuscripts written by the priests in the Register of Baptisms of the Parish of Cres, followed by chapters comprising more detailed analyses and presentations of results related to the annual and monthly distribution of births, then monthly distributions of conception and the relationship of conception with seasonal work. Specific chapters provide reviews of the number and the role of the baptizing priests, of the naming of the baptized, and the (most) frequent and somewhat rarer male and female personal names. The epithets (surnames) of the baptized and their fathers are also treated. A short chapter analyses the number of entries related to twins, who were very rare in the Parish of Cres in the observed period. The paper concludes with a somewhat more detailed chapter explaining the role of godparents, not only in the life of the baptized, but also in the life of the family to which the baptized belonged. The importance of the number of godparents and the (most)frequently chosen godparents in the Cres town community is also emphasized.

As this is the first historical-demographic paper based on one of the registers of the island of Cres, the comparative approach with similar research and published results had to follow those done by experts in the neighbouring Istria researching (semi)urban communities, i.e. parishes of Lindar, Pićan, Pula, Rovinj, Svetvinčenat, Umag, Tar and Tinjan. 


\section{RIASSUNTO}

\section{Il Registro dei battezzati della parrocchia di Cherso (1571 - 1596)}

Il lavoro è nato dalla ricerca e dall'analisi del più antico conservato Registro dei battezzati della parrocchia di Cherso. È stato scritto nel periodo tra il 1571 e il 1596 da addirittura trenta sacerdoti. Ogni sacerdote aveva un particolare stile di scrittura e un diverso modo di formare le lettere, fenomeno comprensibile, il motivo per quale il lavoro sul registro ha rappresentato anche una certa sfida paleografica. Il Registro è scritto in lingua italiana, ovvero in dialetto veneto, caratteristico per i centri urbani dell'isola di Cherso, per via della quasi continua presenza del dominio veneto dal 1145 al 1797, quando cessò di esistere la Repubblica di Venezia.

Nel lavoro è presente una breve recensione analitica delle scritture dei sacerdoti nel Registro dei battezzati della parrocchia di Cherso, alla quale seguono capitoli con dettagliate analisi e presentazioni dei risultati relative alla distribuzione annuale e mensile delle nascite di bambini, alla distribuzione mensile dei concepimenti e la correlazione tra i concepimenti e i lavori stagionali. Nei capitoli a parte ci sono cenni relativi al numero e al ruolo dei sacerdoti che battezzavano, alla scelta dei nomi dei battezzati, e si sono presentati anche i nomi (più) frequenti e quelli più rari, maschili e femminili. Sono inoltre elaborati gli appellativi (cognomi) dei battezzati e dei loro padri. In un capitolo breve è analizzato il numero di iscrizioni relativo alle coppie di gemelli, che erano molto rari nella Parrocchia di Cherso nel periodo interessato. Nell'ultimo capitolo, viene spiegato, in modo accurato, il ruolo dei padrini, non solo nella vita del battezzato ma anche della famiglia a cui appartiene. Si sottolinea l'importanza del numero dei padrini/madrine e i più scelti padrini/ madrine del battesimo nella comunità urbana di Cherso.

Poiché si tratta del primo lavoro storico-demografico basato su uno dei registri dell'isola di Cherso, un approccio comparativo con simili ricerche e risultati pubblicati doveva riguardare quelli realizzati da parte di esperti nella vicina Istria. Si tratta di comunità (semi)urbane, ovvero parrocchie di Lindaro, Pedena,Pola, Rovigno, Sanvincenti, Umago, Torre e Antignana. 